\title{
Decomposing Outcome Differences between HBCU and Non-HBCU Institutions
}

\author{
Mels de Zeeuw, Sameera Fazili, and Julie L. Hotchkiss
}

Working Paper 2020-10

July 2020

\begin{abstract}
This paper investigates differences in outcomes between historically black colleges and universities (HBCU) and traditional college and universities (non-HBCUs) using a standard 0axaca/Blinder decomposition. This method decomposes differences in observed educational and labor market outcomes between HBCU and non-HBCU students into differences in characteristics (both student and institutional) and differences in how those characteristics translate into differential outcomes. Efforts to control for differences in unobservables between the two types of students are undertaken through inverse-probability weighting and propensity score matching methodologies. We find that differences in student characteristics make the largest contributions to each outcome difference. However, some hope in identifying policy levers comes in the form of how characteristics translate into outcomes. For example, whereas HBCUs appear to be doing a better job helping female graduates parlay their education into higher earnings, non-HBCUs are doing a better job in helping graduates in science, technology, engineering, and mathematics translate their training into higher earnings. Patterns and importance of regressors are similar at different points of the distributions of outcomes.
\end{abstract}

JEL classification: I24, I26, C21

Key words: HBCU, decomposition, student debt, returns to education, propensity-score matching, inverse-probability weighting, quantile regression

https://doi.org/10.29338/wp2020-10

The views expressed here are not necessarily those of the Federal Reserve Bank of Atlanta or the Federal Reserve System. The authors thank Kalee Burns and Wenhua Di for helpful comments and suggestions and Fernando Rios-Avila for his support, comments, and Stata expertise. The authors declare that they have no relevant or material financial interests or conflicts that relate to the research in this paper. Any errors are the authors' responsibility.

Please address questions regarding content to Julie L. Hotchkiss, Julie.L.Hotchkiss@atl.frb.org.

Federal Reserve Bank of Atlanta working papers, including revised versions, are available on the Atlanta Fed's website at frbatlanta.org/pubs/WP/. Use the WebScriber Service at frbatlanta.org to receive e-mail notifications about new papers. 


\section{Decomposing Outcome Differences between HBCU and non-HBCU Institutions}

\section{Introduction and Background}

The analysis in this paper decomposes average differences in educational and labor market outcomes observed between graduates from Historically Black Colleges and Universities (HBCUs) and non-HBCUs. The analysis is on an institutional level, making use of the Integrated Postsecondary Education Data System (IPEDS) and College Scorecard data, both from the U.S. Department of Education, for four-year non-profit colleges between the years of 2009 and 2017. While it is true that each HBCU is unique, grouping HBCUs into a distinctive, unified, institutional group is supported by Simms (2014) who provides evidence of cohesiveness in educational outcomes among HBCUs. ${ }^{1}$ Across nearly all educational and earnings metrics, HBCU students perform worse, on average, than non-HBCU students (for example, see Hardy, Kaganda, and Aruguete 2019).

In an effort to identify policy levers that might improve HBCU outcomes, it's important to identify the primary contributors to those differences. In other words, the different outcomes can be the result of (1) differences in institutional characteristics (e.g., tuition and fees), (2) differences in student characteristics (e.g., SAT scores), (3) differences in how institutional characteristics translate into outcomes (e.g., the amount of tuition being more or less important in HBCU outcomes than outcomes among non-HBCU students), and/or (4) differences in how student characteristics translate into outcomes (e.g., does a low SAT score handicap HBCU students more or less than non-HBCU students?). To our knowledge, this paper is the first to

\footnotetext{
${ }^{1}$ Also see Reeder and Schmitt (2013) who provide additional evidence of institutional-type specific contributions of HBCUs on students' abilities to translate their level of motivation into academic success.
} 
disentangle the observed differences in HBCU and non-HBCU student outcomes in this way.

The 1954 Supreme Court's ruling in Brown v. The Board of Education of Topeka declared that segregation in public schools based on race to be unconstitutional. Before this time, many public universities barred African-Americans from attending, making all-Black institutions of higher education the only option for over 90 percent of Black students (Kim 2011). The Supreme Court ruling led many to wonder whether there was an on-going role for HBCUs to play in the education of Black students, especially since HBCUs receive a significant amount of state and federal subsidies (Williams and Davis 2019). Additionally, the "worth" of HBCUs has often been called into question based on lower raw average measures of performance, such as graduation rates and earnings of graduates (for example, see Broady, Todd, and Booth-Bell, 2017, and Minor, 2008, for nuances of this multi-dimensional debate). However, the overwhelming message from the literature is that once student characteristics are controlled for, there is no difference in the graduation rates of Black students between HBCU and non-HBCU students, and in some cases, Black students graduating from HBCUs perform better than Black students graduating from non-HBCUs (for example, see (Ehrenberg and Rothstein 1994; Fryer and Greenstone 2010; Kim 2011; Constantine 1995).

This paper does not delve into the funding debate. However, such a debate should be informed by an accurate picture of the impact of HBCUs have on student outcomes and specifically how or why outcomes differ between HBCUs and non-HBCUs. This paper does that by identifying the contributions of characteristic differences and differences in how those characteristics translate into different outcomes. The outcomes investigated are 6-year Black graduation rates, median debt load of graduates, and median earnings of graduates ten years after matriculation (the start of their college education). There is a large, often conflicting, literature 
exploring each of these outcomes over time. Regarding Black graduation rates, the overwhelming message from the literature is that once student characteristics are controlled for, HBCUs are more successful in graduating Black students than non-HBCUs (for example, see Ehrenberg and Rothstein 1994; Nichols and Evans-Bell 2017; Richards and Awokoya 2010; Franke and DeAngelo 2018). The question of student debt is a complicated one. On the one hand, being burdened by debt can constrain career choices and options if a student is more worried about taking a high-paying job to repay loans rather than finding the right career fit, or if some employers have low-debt requirements for hiring. On the other hand, an ability to take on debt (or order to attend graduate school, for example) may allow greater opportunities. According to Debt.org, citing statistics from the National Center for Education Studies, "About $87 \%$ of Blacks take out student loans at four-year colleges, while $65 \%$ of Hispanics take out student loans" (Fay n.d.); whether this is a help or a hindrance is an open question. Evidence that HBCUs improve labor market outcomes is mixed and has changed over time. Among the most recent evidence, (Elu et al. 2019) report that attending an HBCU confers as much as a 42 percent wage premium on African-American graduates.

As far as we can tell, this paper is the first in the literature to decompose HBCU vs. nonHBCU differences in student educational and labor market outcomes into contributions made by both institutional and student characteristics, as well as differences in how those characteristics translate into student outcomes. This methodology will be useful in identifying potential policy levers that might be applied in improving HBCU student outcomes, relative to non-HBCU student outcomes. With a similar aim, (Kim 2011) decomposes the variation in outcomes into variation in student and institutional characteristics, but they do not distinguish between contributions of characteristics and determinants. We apply a standard Oaxaca/Blinder 
decomposition (Oaxaca 1973; Blinder 1973) to be able to make this distinction. In addition to analyzing differences in outcomes at the mean, we explore determinants of differences at different points in the distribution of outcomes.

Observed student outcomes are necessarily conditional on two processes: the students' decisions to apply to their respective college, and the institutions' decisions to accept the student's application. All we see is the resulting student/institution matriculation pair. However, to the extent that unobserved differences between HBCUs and non-HBCUs are random, or are orthogonal, after controlling for observed characteristics, one can identify the impact of HBCUs through application of propensity-score matching methodology. Nonetheless, if the differences are non-random, then one must be cautious about drawing causal conclusions.

\section{Methodology and Data}

The focuses of this paper is on the institution; all analyses are performed at the institution/year level. Academic institutions are assessed and ranked based on a variety of average outcomes among its students and graduates (for example, see Strauss 2018), so the perspective taken is from that of an institution wanting to know how it's characteristics and those of its students translate into outcomes of interest. This differs from preforming the analysis from the perspective of the student. Whereas an institution might ask whether increasing its share of STEM graduates will increase its graduation rate, a student would ask how much harder it will be to graduate if they choose to major in a STEM subject. While these two questions are obviously related, the focus of the institution is on how they might move the needle in affecting average outcomes. 


\section{$\underline{\text { A. Data }}$}

The data used for the analyses include 4-year private and public non-profit postsecondary educational institutions. Years of analysis are dictated by available consistent data for each outcomes and range between 2009 and 2018; each analysis consists of up to $100 \mathrm{HBCUs}$ and 2,300 non-HBCUs. For most of the data, we rely on the U.S. Department of Education's Integrated Postsecondary Education Data System (IPEDS). IPEDS constitutes a set of surveys that are conducted each year by the Education Department's National Center for Educational Statistics. These surveys yield institution-level data on a variety of topics for post-secondary educational institutions, including 2- or 4-year schools; and public-, private-, and private not-forprofit institutions; and degree- and non-degree granting institutions. One caveat to these data is that the survey is only mandatory for institutions that have a program participation agreement with the Office of Federal Student Aid, and therefore information might be missing on those institutions that do not have this agreement.

From the IPEDS, we obtain data on the six-year graduation rate of Black undergraduate students (one of the outcome variables investigated here). The explanatory variables we derive from IPEDS include whether a school is a HBCU, in-state tuition and fees, the student to faculty ratio, an indicator for whether the institution offers a graduate degree, the share of STEM graduates, the share of non-Hispanic Black students, the share of female students, the share of part-time students, and the share of undergraduates that receive a Pell grant. ${ }^{2}$ We also construct a variable measuring the ratio between endowments and total institution expenditures (the endowment-expense ratio) to evaluate the relative impact of institution endowment, and a

\footnotetext{
${ }^{2}$ Pell grants are a form of Federal student financial aid based on exceptional financial need and, unlike a loan, does not have to be repaid.
} 
measure of per full-time equivalent enrolled student revenues to allow for meaningful comparisons of the resource capacity of institutions. Lastly, we derive information on the degree of urbanization for the location of the institution, the sector (public or private not-for-profit), as well as the size of an institution -- regressors unique to the probit model estimated to construct each institutions propensity-score for the matching process.

For other variables, we rely on the U.S. Department of Education's College Scorecard, which itself aggregates variables from a series of sources, including IPEDS and the National Student Loan Data System. We construct the remaining outcome variables from this data set -the median debt load of graduates and the median earnings 10 years after matriculation, as well as obtain data on the share of first-generation college students, and the average SAT (or equivalent) score of students admitted. Data on the median debt loads of students who completed their course of study at an institution originates from two-year pooled cohorts measured by the U.S. Department of Education's National Student Loan Data System (NSLDS), which is the department's central database for student aid. Data on the earnings for students originates from calculations by the U.S. Department of Treasury, using data from the NSLDS and tax records from the Internal Revenue Service or the U.S. Census Bureau. For these two outcome variables cohort data were not available for 2010-2011, nor for the 2015-2016 academic years and beyond. The dollar amounts for all monetary variables were adjusted to reflect 2016 dollars using the Bureau of Economic Analysis' National Income and Product Accounts' 'Price Indexes for Gross Domestic Product' table's personal consumption expenditure figures.

Table 1 reports means for all $\mathrm{HBCU}$ and non-HBCU observations that have non-missing values for all outcomes and regressors used in primary analysis. In this paper, we focus on 6-year graduation rates among Black students, median student debt load among graduates, and median 
earnings 10 years after matriculation. ${ }^{3}$ Appendix A contains means for each outcome's estimating samples, which will be discussed below. Table 1, however, yields an overall picture of the raw differences in average institutional characteristics, student characteristics, and outcomes. On average, graduates from $\mathrm{HBCU}$ institutions are at a disadvantage relative to their non-HBCU counterparts. Specifically, the Black graduation rate is lower, student loan default rate and debt levels are higher, and earnings and employment rates ten years after matriculation are lower. These differences in outcomes are consistent with those found in the literature (for example, see Baker 2019; Hillman 2015; Houle 2014; Dowd and Malcom 2012; D. V. Price 2004; Baum and Saunders 1998)

[Table 1 about here]

All institutional and student characteristics (except student to faculty ratio) are statistically significantly different across institution type at the 99 percent confidence level. Differences in these average characteristics are well-known (for example, see Hardy, Kaganda, and Aruguete 2019). These significance differences in observed characteristics suggest that differences in unobserved characteristics explaining differential outcomes are also significant; if this is the case, then any conclusions not accounting for those unobserved factors will be biased. In fact, several analyses find that once one controls for observed (and potentially unobserved through matching methodology) characteristics, HBCU outcomes are no longer statistically different, and, in fact, in some cases found to be better than non-HBCU outcomes (for example,

\footnotetext{
${ }^{3}$ Results for additional outcomes of student default rates and employment rates among graduates are available upon request. The decomposition of contributors to differences in these outcomes mirror those reported for contributors to differences in median earnings so are not discussed in the main text. Additionally, results including only "elite" HBCU institutions (see Fryer and Greenstone 2010; Elu et al. 2019) are available upon request, however there were not enough non-missing observations (between 18 and 35 elite $\mathrm{HBCU}$ years) to explain variation in outcomes or differences in those outcomes across institution type with any confidence.
} 
see Hardy, Kaganda, and Aruguete 2019; Franke and DeAngelo 2018; Wood and Palmer 2017; Ehrenberg and Rothstein 1994; Elu et al. 2019; G. N. Price, Spriggs, and Swinton 2011). The methodology below will illustrate how conclusions can differ when the analysis is performed on the raw sample, versus a balanced sample based on matching methodology.

\section{B. Methodology}

In order to determine the relative importance of institutional and student characteristics and how those characteristics translate into differences in outcomes, we estimate a Roy-type model (Roy 1951) assuming random assignment of each observation to be an HBCU. If assignment is not random, then the assumption of ignorability (or exogeneity of the HBCU treatment) fails and additional modifications are needed to account for unobserved differences (those are detailed below). This regression framework models the average outcome of interest for students at non-HBCU $(N)$ and $\operatorname{HBCU}(H)$ institution $i\left(Y_{N, i}\right.$ or $\left.Y_{H, i}\right)$ as a function of a set of institutional characteristics $\left(I_{i}\right)$ and student body characteristics $\left(S_{i}\right)$ :

$$
\begin{array}{ll}
Y_{N, i}=\beta_{N}^{\prime} I_{i}+\alpha_{N}^{\prime} S_{i}+\varepsilon_{N, i} & \text { if non-HBCU institution } \\
Y_{H, i}=\beta_{H}^{\prime} I_{i}+\alpha_{H}^{\prime} S_{i}+\varepsilon_{H, i} & \text { if HBCU institution }
\end{array}
$$

HBCUs and non-HBCUs differ across a variety of institutional characteristics. On average, HBCU institutions have a lower endowment-expense ratio, lower revenue per student, lower tuition and fees, and only slightly higher student to faculty ratios (see Table 1). Student body characteristics differ across institutions even more dramatically. On average, HBCU students are more likely to be first-generation and receive a Pell grant, have lower SAT scores, are less likely to be female, more likely to be Black, less likely to be part-time, but more likely to be STEM graduates. The regressions also include year fixed-effects and the standard errors are clustered at the institution level. 
An Oaxaca/Blinder Decomposition will tell us the relative importance of the differences in these characteristics (and differences in how they translate into outcomes) in determining the observed differences in outcomes (Oaxaca 1973; Blinder 1973). Specifically, the observed differential between an average outcome for non-HBCU $\left(\bar{Y}_{N}\right)$ and $\operatorname{HBCU}\left(\bar{Y}_{H}\right)$ graduates is decomposed as follows: ${ }^{4}$

$$
\bar{Y}_{N}-\bar{Y}_{H}=\left(\overline{\mathrm{M}}_{N}-\overline{\mathrm{M}}_{H}\right)^{\prime}\left\{\boldsymbol{\Psi} \widehat{\Lambda}_{N}+(\boldsymbol{I}-\boldsymbol{\Psi}) \widehat{\Lambda}_{H}\right\}+\left\{(\boldsymbol{I}-\boldsymbol{\Psi})^{\prime} \overline{\mathrm{M}}_{N}+\boldsymbol{\Psi}^{\prime} \overline{\mathrm{M}}_{H}\right\}\left(\widehat{\Lambda}_{N}-\widehat{\Lambda}_{H}\right),
$$

where $\overline{\mathrm{M}}_{l}=\left[\bar{I}_{l}, \bar{S}_{l}\right] ; \widehat{\Lambda}_{l}^{\prime}=\left[\hat{\beta}_{l}^{\prime}, \hat{\alpha}_{l}^{\prime}\right]$; and $\boldsymbol{\Psi}$ is a weight matrix suggested by Jann (2008), derived from a pooled estimation over both groups, plus an indicator for which group the observation is in..$^{5}$ This is a variant of what was first recommended by Neumark (1988) and Oaxaca and Ransom (1994).

We will refer to the first term on the right-hand side of the equation as the characteristic effect and reflects how the differences in characteristics of graduates from the different institution types contribute to the observed outcome differential. ${ }^{6}$ The second term is the coefficient effect and reflects how differences in the valuation of those characteristics of the two institution types contribute to the outcome differential. We will drill down even deeper to explore the role specific regressors play in explaining the differential outcomes. ${ }^{7}$

\section{The Importance of Unobserved Characteristics}

As seen in Table 1, HBCU and non-HBCU institutions differ significantly in both institutional and student characteristics, and student outcomes that we observe are necessarily

\footnotetext{
${ }^{4}$ We will also decompose differences in outcomes at different places in the distribution.

${ }^{5}$ Also see (Cain 1986; Fortin 2008)

${ }^{6}$ This term is often referred to as the "endowment effect," but we will not use that term here in order to avoid confusion with an institution's financial endowment.

${ }^{7}$ Detailed decomposition at the regressor level requires the assuming that the distribution of the regressors is independent of unobservables.
} 
conditional on two processes: the student's decisions to apply to their respective college, and the institutions' decisions to accept the student's application. All we see is the resulting student/institution matriculation pair. If the unobserved student and institutional selection process is correlated with observed characteristics, we can control for some of these unobservables by employing a propensity-score matching methodology (Imbens 2008).

Others have appealed to this methodology to control for unobservables that may be driving differences between HBCU and non-HBCU outcomes in order to be more confident in causal inferences. For example, see Fryer and Greenstone (2010), Montgomery and Montgomery (2012), Hardy, Kaganda, and Aruguete (2019), and Franke and DeAngelo (2018). However, as those papers note, and we acknowledge, to the degree that the outcomes themselves are correlated with unobservables, the results will still be biased. For example, if students (either or both HBCU and non-HBCU) are more likely to select the institution that will result in the best outcomes for them individually, then differences in observed outcomes are likely to understate actual differences. Additionally, if HBCU institutions rely on characteristics unobserved to the researcher to admit students with an eye toward retention or job-placement outcomes, then observed outcome differences are not related to attending an HBCU, but, rather, the institutional selection process. Consequently, the interpretation of the results in this paper as causal will be done with caution.

We will apply propensity-score (p-score) matching methodology in two ways to provide some bounds on the conclusions we draw here. The goal is to create a sample that is more balanced in observed characteristics than we see in the raw data between HBCU and non-HBCU institutions. The theory is that the more similar the "treated" (HBCU) and "control" (non-HBCU) samples are in their observed characteristics, the more similar they will be in their unobserved 
characteristics. The first step in both applications of the methodology is to estimate a p-score for each institution in the data set. This is done by estimating a probit model, using observed characteristics, describing the probability that each institution is an $\mathrm{HBCU}(p(x))$. Then the inverse of the p-score, often referred to as the inverse probability weight $(I P W=p(x) /[1-$ $p(x)]))$ can be used simply as a weight for each observation in the Oaxaca/Blinder decomposition. Since we are not using exactly the regressors in the first-stage probit that we use in the second-stage Oaxaca/Blinder decomposition, we still have some differences in characteristics to help explain the differences in outcomes (see DiNardo, Fortin, and Lemieux 1996; Firpo, Fortin, and Lemieux 2018; Rios-Avila 2020).

Alternatively, the p-score can be used to select non-HBCU "matches" for each $\mathrm{HBCU}$ in the data set, based on how close observations are on the value of their p-scores. ${ }^{8} \mathrm{We}$ will present results using the unweighted sample, the sample weighted by observation p-scores, and the sample of matched observations. Details of and warnings about this methodology are well known. ${ }^{9}$ The matched sample is based on between 1 and 20 "nearest-neighbors" (based on the value of each institution's p-score; in reality each HBCU typically only found one nearest neighbor per year) for each $\mathrm{HBCU}$ in an effort to end up with roughly the same proportion of non-HBCU to HBCU institutions; not all non-HBCUs will be represented in the final matched sample since some may not have found matches. Sampling will be done with replacement, which means each non-HBCU may be used as a control for multiple HBCUs. While reducing bias, this also reduces efficiency, since it typically results in fewer unique observations, and there will be

\footnotetext{
${ }^{8}$ Using propensity scores to create a matched sample has its critics (for example, see King and Nielsen 2019), which is why we also report the results that use inverse propensity scores to simply re-weight the sample.

${ }^{9}$ See Rubin (1977), Rosenbaum and Rubin (1983), Dehejia and Wahba (2002), Imbens (2008), Heckman et al. 1998), and Black (2015).
} 
some non-HBCUs that do not make it into the final matched sample at all. The matching process and Oaxaca/Blinder decomposition is performed separately for each outcome of interest.

Standard errors are clustered at the institution level.

In the first-stage probit (results can be found in Appendix B) regressors describing the probability that an institution is an $\mathrm{HBCU}$ include the endowment-expense ratio, revenue per full-time equivalent, student faculty ratio, an indicator for whether the institution offers graduate degrees, share of first-generation college students, share of female students, share of STEM graduates, the number of students (in categories), and the degree of location urbanization (in categories). ${ }^{10}$ Since the degree of overlap of propensity scores is used to assess how successful the matched sample will serve as a "control" (McDonald et al. 2013), some regressors that nearly perfectly predict HBCU are excluded. Those are tuition, share of students receiving Pell grants, average SAT scores, share of Black students, and share of part-time students. Since these regressors were not used in construction of the p-scores, they are the only ones for whom we would expect to see any characteristic differences remaining in the second-stage Oaxaca/Blinder decomposition, which itself acts as a sort of re-weighting exercise (Kline 2011).

Figure 1 presents the distribution of $\mathrm{p}$-scores for $\mathrm{HBCU}$ and non-HBCU institutions for the sample used to estimate the Oaxaca/Blinder decomposition of the 6-year Black graduation rate (these distributions are are nearly identical for the samples used to investigate the other outcomes). The figure illustrates that although non-HBCU institutions are clustered at low pscore levels, there is significant overlap between the p-scores of HBCU and non-HBCU colleges.

[Figure 1 about here]

\footnotetext{
${ }^{10} \mathrm{We}$ also estimated a specification that included an indicator if the institution granted graduate degrees. Inclusion of this regressor only slightly improved the the first-stage matching and did not at all affect the decomposition conclusions.
} 
Details of how the propensity score helps to re-weight the samples can be seen in the tables in Appendix A. While the differences between the HBCU and weighted non-HBCU are still often statistically significant (because of the large sample sizes), the successful "rebalancing" of the non-HBCU sample is obvious. Less success is apparent with some of the characteristics that still remain quite different even with the re-weighting and in the matched sample, such as share of undergraduates receiving Pell grants, average SAT equivalent scores, share of non-Hispanic Black students, and share of part-time students. These remaining significant differences in characteristics make us skeptical that rebalancing has removed all unobserved characteristics interfering with causal interpretation of the results.

Figure 2 illustrates the result of reweighting for the means of the three outcomes analyzed in this paper. The re-weighting exercise is most successful for the 6-year Black graduation rate comparison between HBCU and non-HBCU students (panel a). While there hasn't been much change over time, the means in the matched non-HBCU sample is much closer to the means of the HBCU sample. Panel (b) of Figure 2 shows the rising debt loads for both HBCU and nonHBCU students. The gap in this outcome is even larger comparing the matched non-HBCU. As will be discussed below, it's unclear whether debt is useful or harmful, but the re-weighting exercise suggests that HBCU students have more debt than their characteristics (matched to nonHBCU students) suggest they should. In other words, given the characteristics of HBCU students, non-HBCU student debt would be lower than it is with their own characteristics, increasing the gap. Median earnings of matched non-HBCU graduates are closer to those of HBCU graduates, but not much closer. Additionally, over this time period we can see that the gap in earnings is growing.

[Figure 2 about here] 


\section{Results}

Tables 2-4 contain the detailed decomposition results for three outcomes: 6-year Black graduation rate, median debt load, and median earnings of graduates ten years after matriculation (regression parameter estimates are available upon request). Each table presents results from the unweighted sample and both the weighted and matched samples. Weighted results use the inverse of the p-score estimated from the first-stage probit estimation in the nearest-neighbor matching process. A matched sample is created using between 1 and 20 nearest-neighbor matches with replacement (in reality each HBCU typically only found one nearest neighbor per year). One will see in all tables the potential bias that could result from not accounting for differences in unobservables. If relying only on the results using the unweighted sample, we would conclude that many more differences between HBCU and non-HBCU institutions significantly contribute to observed outcomes than they likely do (based on the results using the matched samples). The results for each outcome are discussed in turn with a focus on the matched sample.

\section{A. Graduation Rates}

Graduating is, of course, the first step to reaping benefits from a college education. Table 2 reports the decomposition of the differences in average graduation rates between HBCU and non-HBCU institutions. The current literature indicates that once student characteristics are controlled for, HBCUs are more successful in graduating Black students than non-HBCUs (for example, see Ehrenberg and Rothstein 1994; Nichols and Evans-Bell 2017; Richards and Awokoya 2010). This is what we see in Table 2. In the unweighted sample, non-HBCUs graduate Black students at nearly eight statistically significant percentage points higher than HBCU institutions. However, that difference in graduation rates reverses and becomes 
statistically insignificant once we compare "apples with apples" through the propensity score matching methodology.

[Table 2 about here]

Finding this reversal of outcome differences is where other research typically ends. However, through the decomposition details, we can drill-down further to investigate what factors might still be contributing negatively to this relative outcome for HBCUs. In other words, it may be the case that, on average, six-year Black graduation rates don't differ between comparable HBCUs and non-HBCUs, but that average outcome is the sum of factors improving and detracting from the average. The characteristics that act to improve graduation rates of HBCU students relative to non-HBCU students would be worth knowing. We will restrict discussion of regressors contributing to the characteristic effect to those not included in the first stage probit estimation, since those are the characteristics whose differences haven't already been accounted for in the matching process.

Regarding characteristic differences, lower tuition and lower average SAT scores at HBCU institutions work to widen graduation rate gaps in favor of non-HBCUs. This is indicated by the positive and statistically significant contribution of differences in average tuition and SAT scores to the difference in graduation rates $(0.0107$ and 0.0469 , respectively, for the matched sample). These results are being driven by the positive association, primarily among non-HBCU institutions, between higher tuition and higher Black student graduation rates and, within both non-HBCU and HBCU institutions, the association between higher SAT scores and higher graduation rates. ${ }^{11}$ Both of these associations put HBCU students at a disadvantage for graduating. This doesn't mean that HBCUs should simply raise tuition to improve graduation

\footnotetext{
${ }^{11}$ Parameter coefficients from the Oaxaca/Blinder estimations are available upon request.
} 
rates, but that other characteristics of students that attend high-tuition institutions are important in successfully graduating.

On the other hand, a lower share of part-time students at HBCU institutions is working to close the graduation gap. Considering actionable items, then, being aware of the importance of full-time focus on school and remedial needs signaled by SAT scores might prove fruitful for HBCU efforts to improve their graduation rates.

How does the translation of these characteristics into graduation rates differ across institutions? This is what coefficient differences tell us. It is the answer to this question we expect will lead to more actionable items since we expect the institution has a lot to do with the process by which characteristics translate into outcomes. The only difference in coefficients suggestive of potential improvement in relative Black graduation rates is that for first generation college students. The positive contribution of that coefficient difference across institution types ( 0.2344 for the matched sample) indicates that HBCUs can do better in matching resources to those students who might be unfamiliar through familial experiences with what it takes to succeed in a college environment.

\section{B. Student Debt}

Willingness to take on debt and debt burden can have conflicting implications for success. Less willingness to take on debt may restrict educational opportunities (Boatman, Evans, and Soliz 2017; Callender and Jackson 2005; Cunningham and Santiago 2008; Field 2009; Perna 2000), however, a higher debt burden may constrain graduate education decisions and employment choices (for example, see (Rothstein and Rouse 2011; Malcom and Dowd 2012a; Baum and Saunders 1998b; Minicozzi 2005; Baker 2019). Additionally, higher debt is more likely to lead to higher default rates (Jackson and Reynolds 2013) which can have long- 
term consequences for credit availability. All else equal, lower debt is likely a good thing. Table 3 contains the decomposition results for differences in log median debt (in 2016 dollars) between HBCU and non-HBCU students.

[Table 3 about here]

Unlike graduation rates, there is not much difference between the raw means and the means in the matched sample in this outcome. The median debt among HBCU students is about 20 and 30 percent higher than among non-HBCU students (depending on the sample). The contributions to this difference are split roughly evenly between contributions made by differences in characteristics (-0.1506) and contributions made by differences in coefficients (0.1436). These negative contributions tell us that, overall, differences in both characteristics and differences in coefficients contribute to widening the negative debt load difference between nonHBCU and HBCU students (they both put downward pressure on the observed negative debt load differential).

Among the differences in characteristics, differences in the share of students receiving Pell grants widens the negative gap in debt loads (-0.0756 in the matched sample); HBCU students are much more likely to be receiving Pell grants than non-HBCU students and this characteristic contributes to increasing a student's debt load. On the other hand, the contribution of differences in tuition ( 0.0554 in the matched sample) narrows the negative debt load difference. This is because students attending higher tuition institutions tend to incur more debt and non-HBCU institutions have, on average, higher tuitions.

Regarding differences in coefficients, the way in which higher Pell grant receipt translates into higher debt is also worse for HBCU students, widening the negative debt load gap -- for every dollar of Pell grant, a non-HBCU student attains lower debt than an HBCU student. 
The difference in coefficients on STEM graduates (0.1276 in the matched sample) works to narrow the negative debt load gap between non-HBCU and HBCU students. Whereas a higher share of STEM graduates reduces median debt among HBCU graduates, a higher share of STEM graduates increases debt among non-HBCU graduates. This may simply mean that a higher share of non-HBCU STEM graduates go on to incur more debt for graduate study (for example, see (Rothstein and Rouse 2011). Share of part-time students also narrows the debt load gap; whereas the share of part-time students reduces average debt load for both institutions, this is a much stronger effect for HBCU institutions.

A hard to explain result relates to the student faculty ratio at the respective institutions. Whereas the average student faculty ratios are not statistically different from one another in the matched samples, their different contributions to student debt ratios significantly disadvantages graduates from HBCUs. We find, looking at the parameter coefficients for the two groups, higher student faculty ratios decrease debt loads for non-HBCU students, but increases them for HBCU students; these combined widen the negative gap in debt loads between types of students. The mechanism through which student faculty ratios would impact debt loads is unclear, so this regressor might be picking up some other institutional characteristics not controlled for.

\section{Earnings Ten Years After Matriculation}

One of the most important indicators of success among graduates is how a degree translates into earnings. The literature comparing earnings among Black HBCU and non-HBCU graduates is mixed (e.g., see (Ehrenberg and Rothstein 1994; Kim 2011; Constantine 1995), and relative earnings outcomes are shown to depend on career timing (Mykerezi and Mills 2008) and gender (Redd 2000). Although earnings comparisons here are at the institutional level, regressions do control for the share of racial minority and share of female students at the 
institution. Table 1 shows that, as expected in the raw means, students from non-HBCU colleges have higher earnings than HBCU graduates.

Table 4 reports the decomposition of contributions to differences observed in log median earnings of graduates from $\mathrm{HBCU}$ and non-HBCU institutions 10 years after matriculating (the differences six and eight years later are similar, but the difference does decline somewhat over time). The earnings penalty among $\mathrm{HBCU}$ graduates is roughly 30 percent in the unweighted sample, only reducing slightly in the matched samples. Since this difference relates to annual earnings, it may reflect differences in hours as well as difference in hourly pay. Fryer and Greenstone (2010), using individual data on hourly pay find a wage penalty in the late 1990s of about 14 percent, comparing hourly pay among Blacks graduating from HBCUs vs. non-HBCUs. They also find that Black graduates from HBCUs actually experienced a wage premium of about 13 percent in the 1980s. The average difference between non-HBCU and HBCU students in Table 4 are larger since the non-HBCU statistic includes Whites; the analysis of wage differentials here controls for the share of Blacks and women in the regression.

[Table 4 about here]

Overall, 65 percent of the earnings difference in the matched sample $(0.1758 / 0.2685)$ is explained by differences in characteristics, with student body characteristics being much more important than institutional differences. However, differences in tuition between institution types (lower, on average, at HBCUs) work to widen the gap in earnings. If future earnings are correlated with family/parental resources, this could be reflecting HBCU families with fewer resources sending their children to lower-tuition schools.

As a whole, student characteristic differences contribute about half of the overall difference in median earnings. And, differences in the share of students receiving a Pell grant 
widens the difference. Lower average SAT scores among HBCU graduates also works to widen the earning gap.

While the coefficient effect overall only explains one-third of the earnings difference, some of the individual regressors are worth highlighting since several work to reduce the earnings differential. Whereas there is no statistically significant difference in endowmentexpense ratios between $\mathrm{HBCU}$ and non-HBCU institutions in the matched sample, this regressor is positively associated with earnings among HBCU graduates and negatively associated with earnings among non-HBCU graduates (all else equal). While this could be suggesting that HBCUs are somehow using this resource more effectively to increase earnings among their graduates, it might also be correlated with some other unobserved characteristic. Additionally, differences in the coefficients relating the institutional presence of graduate degrees to future earnings significantly reduces the earnings gap. Having graduate programs boosts earnings of both HBCU and non-HBCU students, but the coefficient in the HBCU regression is three times larger than in the non-HBCU regression, indicating that whatever spills over from a graduate program presence to undergraduate students (e.g., higher-ranked faculty, external funding, research opportunities) are more marginally beneficial among HBCU graduates.

Differences in the role tuition plays in the determination of earnings, however, goes in the other direction. While there is no statistically significant relationship between tuition and earnings among HBCU graduates, higher tuition is associated with higher earnings among nonHBCU graduates, with the net result being that higher average tuition among non-HBCUs is working to widen the earnings gap.

Turning to the contribution of coefficient differences for how student characteristics translate into earnings, there is a significant negative relationship between the share of female 
students and median earnings among non-HBCUs, but a positive relationship among HBCUs. Although the coefficient is not statistically significant, it appears that HBCU institutions are doing a better job than non-HBCUs helping female graduates parlay their education into higher earnings.

On the other hand, the differences across institutions in the relationship between share of STEM students and earnings widens the earnings gap. This suggests that non-HBCU graduates are able to better translate their STEM training into higher earnings than HBCU graduates. Since these earning are ten years after matriculation, this difference may be reflecting the higher share of non-HBCU STEM graduates that pursue a graduate degree than HBCU graduates (English and Umbach 2016). This explanation would also be consistent with the finding earlier that a higher share of STEM graduates increases the debt load among non-HBCU institutions, relative to among HBCU institutions.

\section{Differences in Outcomes at Different Points in the Distribution}

The results presented so far decompose differences in each outcome at the means of the distributions. However, the differences in outcomes might vary across the distributions, being different among institutions with, for example, high graduation rates or among institutions whose graduates are at the low end of the earnings distribution. If the distributions have similar shapes (e.g., similarly skewed with similar variance), we are likely to see similar differences in outcomes at different points in the distribution. Figure 3 shows that the distribution of graduation rates by HBCU status are most dissimilar with six-year Black graduation rates being more skewed to the right among non-HBCUs. Similar shapes for the distributions of log median debt load and log median earnings is not unexpected since taking the log will tend to diminish 
differences in the tails. However, even if differences in outcomes are similar at different points of the distributions, factors contributing to those differences might vary.

[Figure 3 about here]

Appendix $\mathrm{C}$ contains tables for each outcome decomposed at the 25th, 50th, and 75th percentiles. While the overall conclusions derived from decomposing the differences at the mean, there are some variations worth highlighting. The first thing we see in the tables is that differences in outcomes across the distributions reflects what we expected from looking at Figure 3. That is, differences across HBCU status in debt load and earnings are of similar magnitude and statistical significance, whereas the (negative) difference in graduation rates is most pronounced in the bottom quartile of the distributions.

Factors contributing most to differences in average debt loads (i.e., coefficient effects for endowment-expense ratio, student faculty ratio, share of students receiving Pell grants, and share of part-time students), have their greatest impact in explaining differences at the bottom of the distribution (among institutions whose students have lower debt loads). So, for example, we saw that differences in how the share of part-time students is related to median debt load (the coefficient effect) worked to reduce the debt load gap between HBCU and non-HBCU institutions. However, from Table $\mathrm{C} 2$ we see that this is only the case in the bottom half of the distribution (among institutions where students have relative low levels of debt).

There seems to be more nuance across factors explaining earnings differences across the distribution. For example, the importance of differences in SAT scores in widening the earnings gap is most important comparing institutions with student earnings in the 75th percentile. However, differences in the way in which STEM graduates translates into earnings is more important in the bottom of the distribution. This implies that non-HBCU's are doing an even 
better job than HBCU institutions at getting the most out of a STEM education for their students who end up with relatively lower earnings than for students who end up with higher earnings.

\section{Conclusions, Implications, and Caveats}

When considering levers to improve HBCU outcomes, the policy path is not always clear. The greatest contributing factors to explaining differences in outcomes are student characteristics and there is not much an institution can do to change the characteristics of its student body to improve outcomes -- other than skimming the best students (e.g., set a higher minimum SAT score for admission) or not offering any financial aid (i.e., reducing the chance that admitted students are Pell grant eligible).

However, if we look to differences in institutional characteristics, lower tuition and fees among HBCU consistently contributes significantly to differences in outcomes -- narrowing the gap in debt loads, but widening the gaps in graduation rates and earnings. Additionally, knowing how resources translate into outcomes (evidenced through differences in estimated coefficients) could also be useful. For example, a higher share of STEM graduates increases both debt loads and earnings among non-HBCU students relative to HBCU students. This can be explained by non-HBCU institutions doing a better job getting their STEM graduates to go on for graduate education. Additionally, spillovers from graduate programs to undergraduate experiences related to higher earnings appears to be more valuable among HBCU institutions than among nonHBCU institutions. While we identified some nuances across the distribution of outcomes, the patterns and importance of regressors are similar.

The results presented in this paper also illustrate how not accounting for unobserved differences between groups could lead to erroneous policy recommendations. For example, based on the unweighted sample results, we would have concluded that HBCUs are not as 
successful as non-HBCUs in graduating Black students -- the difference in coefficients between non-HBCUs and HBCUs on the share of Black students was positive suggesting that nonHBCUs are more successful in translating higher shares of Black students into higher graduation rates. This is just one example of significant differences in both characteristics and coefficients across institution type seen in the raw data, but disappear in the matched sample, suggesting that the strategy for reducing bias has been effective. However, there are two important caveats to interpreting the results in this paper as causal. Even though the matching methodology is expected to eliminate bias attributable to unobservables, it will only be successful to the extent that those unobservables are correlated with observed characteristics used to create the matched sample. In addition, there is also a chance that the unobservables are correlated with the outcome. If, for example, students positively select to the institution that will result in the best outcomes for them individually, then differences in observed outcomes are likely an underestimate of actual differences. 


\section{References}

Baker, Dominique. 2019. "A Case Study of Undergraduate Debt, Repayment Plans, and Postbaccalaureate Decision-Making among Black Students at HBCUs.” Journal of Student Financial Aid 48 (2). https://ir.library.louisville.edu/jsfa/vol48/iss2/1.

Baum, Sandy, and Diane Saunders. 1998a. "Life After Debt: Results of the National Student Loan Survey. Selected Text from the Final Report." Journal of Student Financial Aid 28 (3): 7-23.

. 1998b. "Life After Debt: Results of the National Student Loan Survey Selected Text

From the Final Report." Journal of Student Financial Aid 28 (3): 7-23.

Black, Dan. 2015. "Matching as a Regression Estimator." IZA World of Labor. https://doi.org/10.15185/izawol.186.

Blinder, Alan S. 1973. "Wage Discrimination: Reduced Form and Structural Estimates." The Journal of Human Resources 8 (4): 436-55. https://doi.org/10.2307/144855.

Boatman, Angela, Brent J. Evans, and Adela Soliz. 2017. "Understanding Loan Aversion in Education: Evidence from High School Seniors, Community College Students, and Adults.” AERA Open 3 (1): 233285841668364. https://doi.org/10.1177/2332858416683649.

Broady, Kristen E., Curtis L. Todd, and Darlene Booth-Bell. 2017. "Dreaming and Doing at Georgia HBCUs: Continued Relevancy in 'Post-Racial' America." The Review of Black Political Economy 44 (1): 37-54.

Cain, Glen G. 1986. "Chapter 13 The Economic Analysis of Labor Market Discrimination: A Survey." In Handbook of Labor Economics, 1:693-785. Elsevier. https://doi.org/10.1016/S1573-4463(86)01016-7.

Callender, Claire, and Jonathan Jackson. 2005. "Does the Fear of Debt Deter Students from Higher Education?” Journal of Social Policy 34 (4): 509-40. https://doi.org/10.1017/S004727940500913X.

Constantine, Jill M. 1995. "The Effect of Attending Historically Black Colleges and Universities on Future Wages of Black Students." Industrial and Labor Relations Review 48 (3): $531-$ 46. https://doi.org/10.2307/2524780.

Cunningham, Alisa F., and Deborah A. Santiago. 2008. "Student Aversion to Borrowing: Who Borrows and Who Doesn't." Institute for Higher Education Policy. https://files.eric.ed.gov/fulltext/ED503684.pdf.

Dehejia, Rajeev H., and Sadek Wahba. 2002. "Propensity Score-Matching Methods for Nonexperimental Causal Studies." The Review of Economics and Statistics 84 (1): 15161.

DiNardo, John, Nicole M. Fortin, and Thomas Lemieux. 1996. "Labor Market Institutions and the Distribution of Wages, 1973-1992: A Semiparametric Approach." Econometrica 64 (5): 1001-44. https://doi.org/10.2307/2171954.

Ehrenberg, Ronald G., and Donna S. Rothstein. 1994. "Do Historically Black Institutions of Higher Education Confer Unique Advantages Do Historically Black Institutions of Higher Education Confer Unique Advantages on Black Students? An Initial Analysis on Black Students? An Initial Ana." In Choices and Consequences: Contemporary Policy Issues in Education, 89-137. Cornell University Press.

Elu, Juliet U., Jared Ireland, David Jeffries, Ivory Johnson, Ellis Jones, Dimone Long, Gregory N. Price, et al. 2019. "The Earnings and Income Mobility Consequences of Attending a Historically Black College/University: Matching Estimates From 2015 U.S. Department 
of Education College Scorecard Data." The Review of Black Political Economy 46 (3): 171-92. https://doi.org/10.1177/0034644619866201.

English, David, and Paul D. Umbach. 2016. "Graduate School Choice: An Examination of Individual and Institutional Effects." The Review of Higher Education 39 (2): 173-211.

Fay, Bill. n.d. "Key Figures Behind America's Consumer Debt: Demographics of Debt.” Blog. Debt.Org (blog). Accessed February 23, 2020. https://www.debt.org/faqs/americans-indebt/demographics/.

Field, Erica. 2009. "Educational Debt Burden and Career Choice: Evidence from a Financial Aid Experiment at NYU Law School.” American Economic Journal: Applied Economics 1 (1): 1-21. http://dx.doi.org/10.1257/app.1.1.1.

Firpo, Sergio P., Nicole M. Fortin, and Thomas Lemieux. 2018. "Decomposing Wage

Distributions Using Recentered Influence Function Regressions.” Econometrics 6 (2): 28. https://doi.org/10.3390/econometrics6020028.

Fortin, Nicole M. 2008. "The Gender Wage Gap among Young Adults in the United States: The Importance of Money versus People." The Journal of Human Resources 43 (4): 884-918.

Franke, Ray, and Linda DeAngelo. 2018. "Degree Attainment for Black Students at HBCUs and PWIs: A Propensity Score Matching Approach.” In , 30. New York, NY.

Fryer, Roland G., and Michael Greenstone. 2010. "The Changing Consequences of Attending Historically Black Colleges and Universities." American Economic Journal: Applied Economics 2 (1): 116-48.

Hardy, Precious M., Elizabeth J. Kaganda, and Mara S. Aruguete. 2019. "Below the Surface: HBCU Performance, Social Mobility, and College Ranking.” Journal of Black Studies 50 (5): 468-83. https://doi.org/10.1177/0021934719847910.

Heckman, James, Hidehiko Ichimura, Jeffrey Smith, and Petra Todd. 1998. "Characterizing Selection Bias Using Experimental Data.” Econometrica 66 (5): 1017-98. https://doi.org/10.2307/2999630.

Hillman, Nicholas W. 2015. "Borrowing and Repaying Student Loans.” Journal of Student Financial Aid 45 (3). https://eric.ed.gov/?id=EJ1080469.

Houle, Jason N. 2014. "Disparities in Debt: Parents' Socioeconomic Resources and Young Adult Student Loan Debt." Sociology of Education 87 (1): 53-69. https://doi.org/10.1177/0038040713512213.

Imbens, Guido W. 2008. "Nonparametric Estimation of Average Treatment Effects Under Exogeneity: A Review." The Review of Economics and Statistics 86 (1): 4-29.

Jackson, Brandon A., and John R. Reynolds. 2013. "The Price of Opportunity: Race, Student Loan Debt, and College Achievement." Sociological Inquiry 83 (3): 335-68. https://doi.org/10.1111/soin.12012.

Jann, Ben. 2008. “The Blinder-Oaxaca Decomposition for Linear Regression Models.” The Stata Journal 8 (4): 453-79.

Kim, Mikyong Minsun. 2011. "Early Career Earnings of African American Students: The Impact of Attendance at Historically Black versus White Colleges and Universities." Journal of Negro Education 80 (4): 505-20.

King, Gary, and Richard Nielsen. 2019. "Why Propensity Scores Should Not Be Used for Matching." Political Analysis 27 (4): 435-54. https://doi.org/10.1017/pan.2019.11.

Kline, Patrick. 2011. "Oaxaca-Blinder as a Reweighting Estimator." American Economic Review 101 (3): 532-37. https://doi.org/10.1257/aer.101.3.532. 
Malcom, Lindsey E., and Alicia C. Dowd. 2012a. "The Impact of Undergraduate Debt on the Graduate School Enrollment of STEM Baccalaureates." The Review of Higher Education 35 (2): 265-305. https://doi.org/10.1353/rhe.2012.0007.

. 2012b. "The Impact of Undergraduate Debt on the Graduate School Enrollment of STEM Baccalaureates." Review of Higher Education - REV HIGHER EDUC 35 (December): 265-305. https://doi.org/10.1353/rhe.2012.0007.

McDonald, Robert J., Jennifer S. McDonald, David F. Kallmes, and Rickey E. Carter. 2013. "Behind the Numbers: Propensity Score Analysis - A Primer for the Diagnostic Radiologist." Radiology 269 (3): 640-45. https://doi.org/10.1148/radiol.13131465. Minicozzi, Alexandra. 2005. "The Short Term Effect of Educational Debt on Job Decisions." Economics of Education Review 24 (4): 417-30. https://doi.org/10.1016/j.econedurev.2004.05.008.

Minor, James T. 2008. "A Contemporary Perspective on the Role of Public HBCUs: Perspicacity from Mississippi." The Journal of Negro Education 77 (4): 323-35.

Montgomery, Rene, and Beronda L. Montgomery. 2012. "Graduation Rates at Historically Black Colleges and Universities: An Underperforming Performance Measure for Determining Institutional Funding Policies." Journal of Continuing Higher Education 60 (2): 93-109. https://doi.org/10.1080/07377363.2012.690623.

Mykerezi, Elton, and Bradford F. Mills. 2008. "The Wage Earnings Impact of Historically Black Colleges and Universities." Southern Economic Journal 75 (1): 173-87. https://doi.org/10.2307/20112033.

Neumark, David. 1988. "Employers' Discriminatory Behavior and the Estimation of Wage Discrimination.” The Journal of Human Resources 23 (3): 279. https://doi.org/10.2307/145830.

Nichols, Andrew H., and Denzel Evans-Bell. 2017. “A Look At Black Student Success: Identifying Top- and Bottom-Performing Institutions.” Report. The Education Trust. https://vtechworks.lib.vt.edu/handle/10919/83663.

Oaxaca, Ronald. 1973. "Male-Female Wage Differentials in Urban Labor Markets." International Economic Review 14 (3): 693-709. https://doi.org/10.2307/2525981.

Oaxaca, Ronald, and Michael Ransom. 1994. "On Discrimination and the Decomposition of Wage Differentials." Journal of Econometrics 61 (1): 5-21.

Perna, Laura Walter. 2000. "Differences in the Decision to Attend College among African Americans, Hispanics, and Whites.” The Journal of Higher Education 71 (2): 117-41. https://doi.org/10.2307/2649245.

Price, Derek V. 2004. "Educational Debt Burden Among Student Borrowers: An Analysis of the Baccalaureate \& Beyond Panel, 1997 Follow-Up." Research in Higher Education 45 (7): 701-37. https://doi.org/10.1023/B:RIHE.0000044228.54798.4c.

Price, Gregory N., William Spriggs, and Omari H. Swinton. 2011. "The Relative Returns to Graduating from a Historically Black College/University: Propensity Score Matching Estimates from the National Survey of Black Americans." The Review of Black Political Economy 38 (2): 103-30. https://doi.org/10.1007/s12114-011-9088-0.

Redd, Kenneth E. 2000. HBCU Graduates: Employment Earnings and Success after College. New Agenda Series[TM], Volume 2, Number 4. https://eric.ed.gov/?id=ED449716.

Richards, David A.R., and Janet T Awokoya. 2010. "Understanding HBCU Retention and Completion." UNCF: Patterson Research Institute. https://uncf.org/wpcontent/uploads/PDFs/Understanding_HBCU_Retention_and_Completion.pdf. 
Rios-Avila, Fernando. 2020. "Recentered Influence Functions (RIFs) in Stata: RIF Regression and RIF Decomposition." The Stata Journal 20 (1): 51-94. https://doi.org/10.1177/1536867X20909690.

Rosenbaum, Paul R., and Donald B. Rubin. 1983. "The Central Role of the Propensity Score in Observational Studies for Causal Effects." Biometrika 70 (1): 41-55. https://doi.org/10.1093/biomet/70.1.41.

Rothstein, Jesse, and Cecilia Elena Rouse. 2011. "Constrained after College: Student Loans and Early-Career Occupational Choices.” Journal of Public Economics 95 (1): 149-63. https://doi.org/10.1016/j.jpubeco.2010.09.015.

Roy, A. D. 1951. "Some Thoughts on the Distribution of Earnings." Oxford Economic Papers, New Series, 3 (2): 135-46.

Rubin, Donald B. 1977. "Assignment to Treatment Group on the Basis of a Covariate." Journal of Educational Statistics 2 (1): 1-26. https://doi.org/10.2307/1164933.

Strauss, Valerie. 2018. "U.S. News Changed the Way It Ranks Colleges. It's Still Ridiculous." Washington Post, September 12, 2018.

https://www.washingtonpost.com/education/2018/09/12/us-news-changed-way-it-rankscolleges-its-still-ridiculous/.

Williams, Krystal L., and BreAnna L. Davis. 2019. "Public and Private Investments and Divestments in Historically Black Colleges and Universities.” Issue Brief. Washington, D.C.: American Council on Education.

Wood, J. Luke, and Robert T. Palmer. 2017. "HBCU Labor Market Outcomes: An Examination Of Baccalaureate Degree Holders' Earnings And Benefits." In Black Colleges Across the Diaspora: Global Perspectives on Race and Stratification in Postsecondary Education, 14:171-86. Advances in Education in Diverse Communities: Research, Policy and Praxis. Emerald Insight. https://doi.org/10.1108/S1479-358X20160000014009. 
Figure 1 Distribution of HBCU and non-HBCU institutions by their p-score value.

\section{6-year black graduation rate}

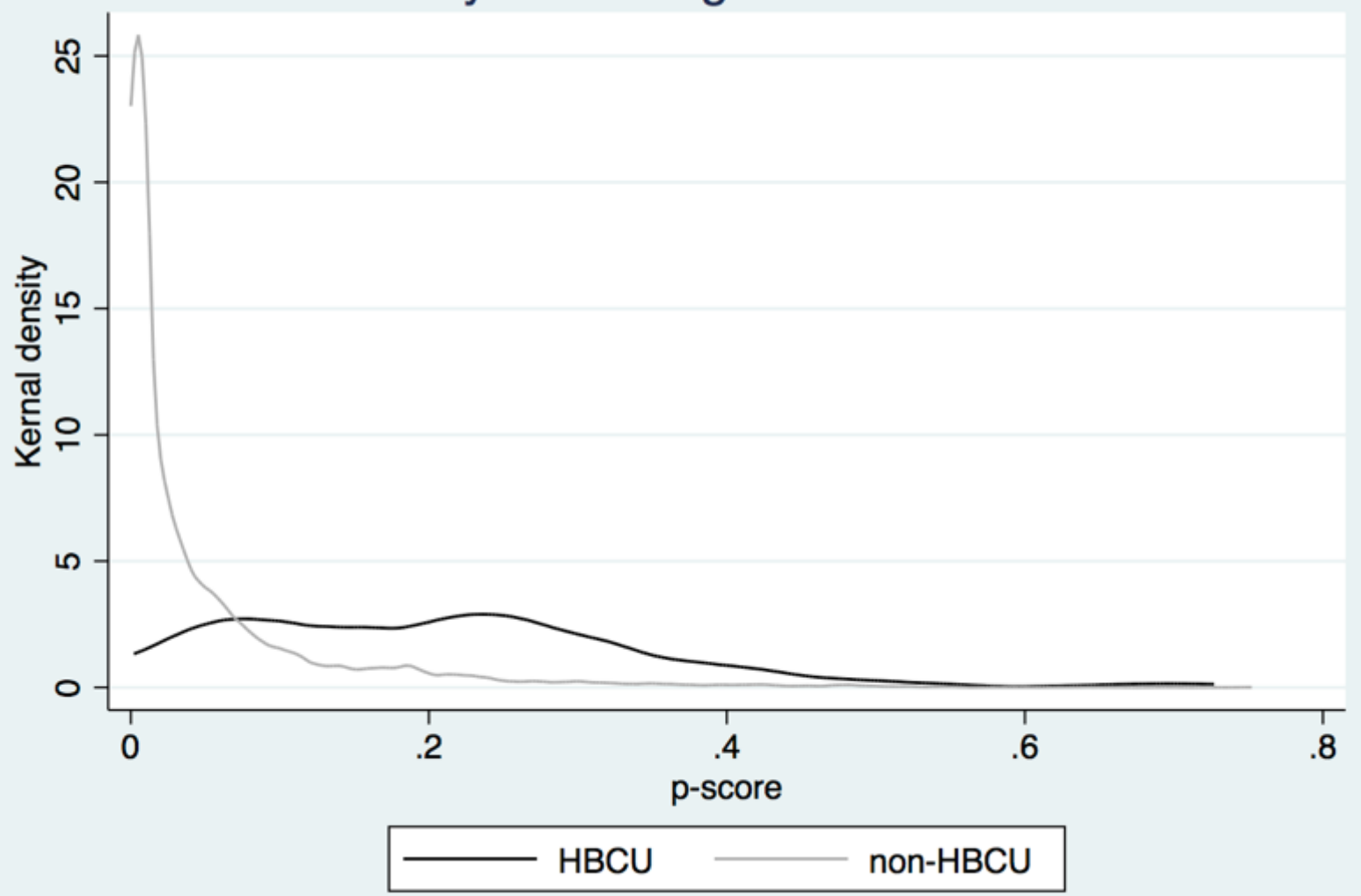


Figure 2 Raw and re-weighted sample averages of (and differences in) graduation rates, log median debt, and log earnings over time, HBCU and non-HBCU institutions.

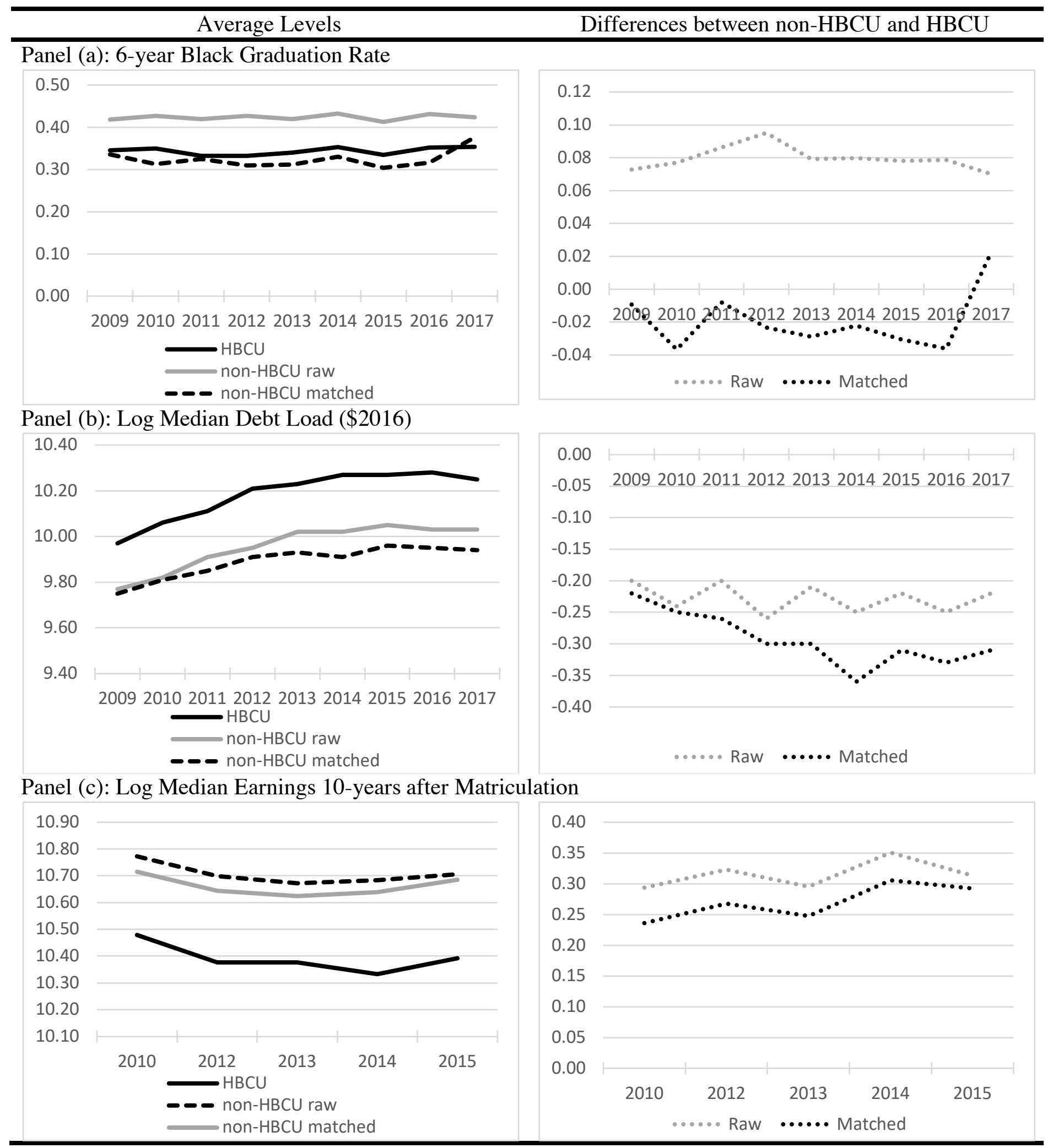


Figure 3 Comparing outcome distributions across HBCU status.

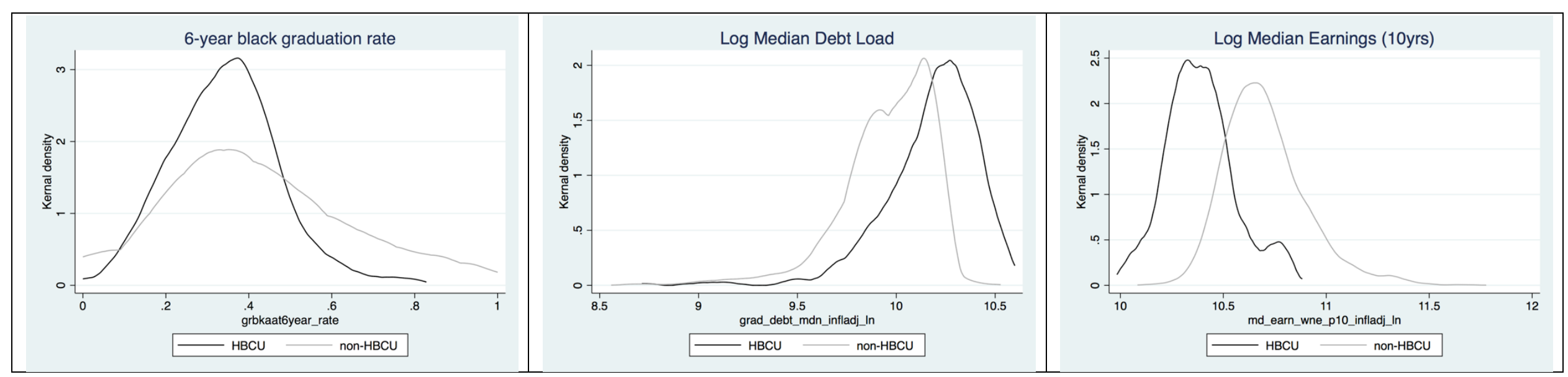


Table 1 Sample means of HBCU and non-HBCU graduates, select sample with non-missing values for all outcome variables.

\begin{tabular}{lccc}
\hline & Data & & \\
Individual Characteristics & Source & HBCU & non-HBCU \\
\hline Outcome measures & & & \\
6-year Black graduation rate & IPEDS & .345 & .44 \\
& & {$[.1293]$} & {$[.2245]$} \\
Median debt load of graduates & Scorecard & $\$ 27949.82$ & $\$ 21828.7$ \\
& & {$[5459.994]$} & {$[4453.9]$} \\
Median Earnings 10yrs after matriculation & Scorecard & $\$ 33,013.9$ & $\$ 46,223.78$ \\
& & {$[5841.601]$} & {$[10123.98]$} \\
& & & \\
Institutional Characteristics & & & \\
Endowment-expense ratio & IPEDS & .4405 & .9834 \\
& & {$[.6097]$} & {$[1.497]$} \\
Revenue per fte - \$1000s & IPEDS & 28.9738 & 34.0933 \\
& & {$[11.0346]$} & {$[37.719]$} \\
In-state tuition and fees $-\$ 1000$ s & IPEDS & 10.2717 & 20.7318 \\
Student to Faculty ratio & & {$[5.9224]$} & {$[12.8449]$} \\
& IPEDS & 15.3705 & 15.0738 \\
Graduate program $=1$ & & {$[2.8711]$} & {$[4.1964]$} \\
& IPEDS & .5357 & .6713 \\
& & {$[.4998]$} & {$[.4698]$} \\
Student Characteristics & & & \\
Share of 1st gen. college students & Scorecard & 38.7727 & 32.4633 \\
& & {$[7.6646]$} & {$[10.2413]$} \\
Share of undergrads who receive a Pell grant & IPEDS & 67.0227 & 32.8092 \\
& & {$[12.6215]$} & {$[12.3693]$} \\
Avg SAT equiv. score of students admitted & Scorecard & 866.0089 & 1077.242 \\
& & {$[72.6263]$} & {$[123.296]$} \\
Share of female students & IPEDS & 60.4762 & 57.3233 \\
Share of Non-Hispanic Black Students & & {$[12.3074]$} & {$[10.9163]$} \\
Share of STEM graduates & IPEDS & 82.5345 & 9.5717 \\
& & {$[17.0052]$} & {$[9.0992]$} \\
Share of part-time students & IPEDS & 15.7876 & 13.9576 \\
Observation years & & {$[7.5073]$} & {$[12.505]$} \\
Number of unique institutions & IPEDS & 14.0124 & 21.7681 \\
& & {$[8.9863]$} & {$[14.099]$} \\
& & 224 & 4,241 \\
& & 61 & 1,166 \\
\hline
\end{tabular}

Notes: Standard deviations in brackets. Means are for the raw data, for observation not missing any of the regressors used in any of the analyses. Details of all estimating samples (the sizes of which will differ slightly depending on outcome) are in the appendix. All difference in means (except student to faculty ratio) across institution type are all statistically significantly different from each other at the 99 percent confidence level based on a standard Z-test. All dollar values are in 2016 dollars. 
Table 2. Decomposition of differences in 6-year Black graduation rates, comparing HBCU and non-HBCU graduates.

\begin{tabular}{|c|c|c|c|}
\hline & $\begin{array}{c}\text { Unweighted } \\
\text { Sample }\end{array}$ & $\begin{array}{c}\text { Weighted } \\
\text { Sample }\end{array}$ & $\begin{array}{l}\text { Matched } \\
\text { Sample }\end{array}$ \\
\hline 6-year Black graduation rate non-HBCU graduates & $\begin{array}{c}0.4223 * * * \\
(0.0059)\end{array}$ & $\begin{array}{c}0.3319 * * * \\
(0.0099)\end{array}$ & $\begin{array}{c}0.3263^{* * *} \\
(0.0096)\end{array}$ \\
\hline 6-year Black graduation rate $\mathrm{HBCU}$ graduates & $\begin{array}{c}0.3429 * * * \\
(0.0155)\end{array}$ & $\begin{array}{c}0.3429 * * * \\
(0.0155)\end{array}$ & $\begin{array}{c}0.3429 * * * \\
(0.0155)\end{array}$ \\
\hline Observed graduation rate differential & $\begin{array}{c}0.0794 * * * \\
(0.0166)\end{array}$ & $\begin{array}{l}-0.0110 \\
(0.0184)\end{array}$ & $\begin{array}{l}-0.0166 \\
(0.0182)\end{array}$ \\
\hline \multicolumn{4}{|l|}{ Contribution of differences in: } \\
\hline Characteristics $\quad\left(\overline{\mathrm{M}}_{N}-\overline{\mathrm{M}}_{H}\right)^{\prime}\left\{\boldsymbol{\Psi} \widehat{\Lambda}_{N}+(\boldsymbol{I}-\boldsymbol{\Psi}) \widehat{\Lambda}_{H}\right\}=$ & $\begin{array}{c}0.0988 * * * \\
(0.0248)\end{array}$ & $\begin{array}{c}0.0215 \\
(0.0315)\end{array}$ & $\begin{array}{c}0.0032 \\
(0.0269)\end{array}$ \\
\hline Institutional characteristics & $\begin{array}{c}0.0405 * * * \\
(0.0057)\end{array}$ & $\begin{array}{c}0.0122 * * \\
(0.0054)\end{array}$ & $\begin{array}{c}0.0121 * * \\
(0.0056)\end{array}$ \\
\hline Endowment-expense ratio & $\begin{array}{c}0.0060 * * * \\
(0.0017)\end{array}$ & $\begin{array}{c}0.0001 \\
(0.0016)\end{array}$ & $\begin{array}{c}0.0004 \\
(0.0016)\end{array}$ \\
\hline Revenue per fte $-\$ 1000$ s & $\begin{array}{c}0.0007 \\
(0.0005)\end{array}$ & $\begin{array}{c}0.0008 \\
(0.0010)\end{array}$ & $\begin{array}{c}0.0008 \\
(0.0011)\end{array}$ \\
\hline In-state tuition and fees $-\$ 1000 \mathrm{~s}$ & $\begin{array}{c}0.0341 * * * \\
(0.0053)\end{array}$ & $\begin{array}{c}0.0116^{* * *} \\
(0.0044)\end{array}$ & $\begin{array}{c}0.0107 * * \\
(0.0047)\end{array}$ \\
\hline Student to Faculty ratio & $\begin{array}{c}-0.0029 * * \\
(0.0015)\end{array}$ & $\begin{array}{l}-0.0000 \\
(0.0007)\end{array}$ & $\begin{array}{c}0.0001 \\
(0.0006)\end{array}$ \\
\hline Graduate program $=1$ & $\begin{array}{c}0.0026 \\
(0.0025)\end{array}$ & $\begin{array}{l}-0.0004 \\
(0.0023)\end{array}$ & $\begin{array}{c}0.0000 \\
(0.0023)\end{array}$ \\
\hline Student body characteristics & $\begin{array}{c}0.0582 * * \\
(0.0232)\end{array}$ & $\begin{array}{c}0.0089 \\
(0.0298)\end{array}$ & $\begin{array}{l}-0.0093 \\
(0.0251)\end{array}$ \\
\hline Share of 1st gen. college students & $\begin{array}{c}0.0218 * * * \\
(0.0050)\end{array}$ & $\begin{array}{c}0.0038 \\
(0.0070)\end{array}$ & $\begin{array}{c}0.0006 \\
(0.0067)\end{array}$ \\
\hline Share of undergrads who receive a Pell grant & $\begin{array}{c}0.0659 * * * \\
(0.0130)\end{array}$ & $\begin{array}{c}0.0208 \\
(0.0127)\end{array}$ & $\begin{array}{c}0.0153 \\
(0.0135)\end{array}$ \\
\hline Average SAT equivalent score of students admitted & $\begin{array}{c}0.1197 * * * \\
(0.0116)\end{array}$ & $\begin{array}{c}0.0503 * * * \\
(0.0132)\end{array}$ & $\begin{array}{c}0.0469 * * * \\
(0.0131)\end{array}$ \\
\hline Share of female students & $\begin{array}{l}-0.0062 \\
(0.0039)\end{array}$ & $\begin{array}{l}-0.0021 \\
(0.0030)\end{array}$ & $\begin{array}{l}-0.0013 \\
(0.0031)\end{array}$ \\
\hline Share of Non-Hispanic Black Students & $\begin{array}{c}-0.1300 * * * \\
(0.0230)\end{array}$ & $\begin{array}{l}-0.0427 \\
(0.0309)\end{array}$ & $\begin{array}{l}-0.0448 \\
(0.0279)\end{array}$ \\
\hline Share of STEM graduates & $\begin{array}{c}0.0000 \\
(0.0008)\end{array}$ & $\begin{array}{l}-0.0007 \\
(0.0013)\end{array}$ & $\begin{array}{l}-0.0007 \\
(0.0012)\end{array}$ \\
\hline Share of part-time students & $\begin{array}{c}-0.0131 * * * \\
(0.0029)\end{array}$ & $\begin{array}{c}-0.0204 * * * \\
(0.0064)\end{array}$ & $\begin{array}{c}-0.0253 * * * \\
(0.0080)\end{array}$ \\
\hline Year fixed effects & $\begin{array}{c}0.0001 \\
(0.0003)\end{array}$ & $\begin{array}{c}0.0004 \\
(0.0004)\end{array}$ & $\begin{array}{c}0.0004 \\
(0.0004)\end{array}$ \\
\hline
\end{tabular}




\begin{tabular}{|c|c|c|c|}
\hline & $\begin{array}{c}\text { Unweighted } \\
\text { Sample }\end{array}$ & $\begin{array}{l}\text { Weighted } \\
\text { Sample }\end{array}$ & $\begin{array}{c}\text { Matched } \\
\text { Sample }\end{array}$ \\
\hline Coefficients $\quad\left\{(\boldsymbol{I}-\boldsymbol{\Psi})^{\prime} \overline{\mathrm{M}}_{N}+\boldsymbol{\Psi}^{\prime} \overline{\mathrm{M}}_{H}\right\}\left(\widehat{\Lambda}_{N}-\widehat{\Lambda}_{H}\right)=$ & $\begin{array}{c}-0.0193 \\
(0.0219)\end{array}$ & $\begin{array}{c}-0.0325 \\
(0.0309)\end{array}$ & $\begin{array}{c}-0.0198 \\
(0.0249)\end{array}$ \\
\hline Institutional characteristics & $\begin{array}{c}0.0810 \\
(0.0613)\end{array}$ & $\begin{array}{c}0.0636 \\
(0.0690)\end{array}$ & $\begin{array}{l}0.0607 \\
(0.0714)\end{array}$ \\
\hline Endowment-expense ratio & $\begin{array}{l}-0.0122 \\
(0.0091)\end{array}$ & $\begin{array}{l}-0.0170^{*} \\
(0.0101)\end{array}$ & $\begin{array}{l}-0.0166 \\
(0.0106)\end{array}$ \\
\hline Revenue per fte $-\$ 1000$ s & $\begin{array}{c}0.0033 \\
(0.0227)\end{array}$ & $\begin{array}{c}0.0057 \\
(0.0230)\end{array}$ & $\begin{array}{c}0.0067 \\
(0.0229)\end{array}$ \\
\hline In-state tuition and fees $-\$ 1000 \mathrm{~s}$ & $\begin{array}{c}0.0364 \\
(0.0233)\end{array}$ & $\begin{array}{c}0.0396 \\
(0.0257)\end{array}$ & $\begin{array}{c}0.0365 \\
(0.0262)\end{array}$ \\
\hline Student to Faculty ratio & $\begin{array}{c}0.0348 \\
(0.0451)\end{array}$ & $\begin{array}{c}0.0164 \\
(0.0517)\end{array}$ & $\begin{array}{c}0.0159 \\
(0.0540)\end{array}$ \\
\hline Graduate program $=1$ & $\begin{array}{c}0.0187 \\
(0.0143)\end{array}$ & $\begin{array}{c}0.0190 \\
(0.0153)\end{array}$ & $\begin{array}{c}0.0182 \\
(0.0156)\end{array}$ \\
\hline Student body characteristics & $\begin{array}{c}0.6906 * * * \\
(0.1866)\end{array}$ & $\begin{array}{c}0.4630 * * \\
(0.2226)\end{array}$ & $\begin{array}{c}0.4824 * * \\
(0.2308)\end{array}$ \\
\hline Share of 1 st gen. college students & $\begin{array}{c}0.2475 * * * \\
(0.0850)\end{array}$ & $\begin{array}{c}0.2415 * * * \\
(0.0927)\end{array}$ & $\begin{array}{c}0.2344 * * \\
(0.0969)\end{array}$ \\
\hline Share of undergrads who receive a Pell grant & $\begin{array}{l}-0.0747 \\
(0.0521)\end{array}$ & $\begin{array}{c}0.0237 \\
(0.0498)\end{array}$ & $\begin{array}{c}0.0551 \\
(0.0538)\end{array}$ \\
\hline Average SAT equivalent score of students admitted & $\begin{array}{c}0.3643 * * * \\
(0.1089)\end{array}$ & $\begin{array}{c}0.2194 \\
(0.1450)\end{array}$ & $\begin{array}{c}0.2068 \\
(0.1497)\end{array}$ \\
\hline Share of female students & $\begin{array}{c}0.0517 \\
(0.0442)\end{array}$ & $\begin{array}{l}-0.0108 \\
(0.0546)\end{array}$ & $\begin{array}{c}0.0030 \\
(0.0553)\end{array}$ \\
\hline Share of Non-Hispanic Black Students & $\begin{array}{l}0.0916^{* *} \\
(0.0447)\end{array}$ & $\begin{array}{l}-0.0155 \\
(0.0421)\end{array}$ & $\begin{array}{l}-0.0142 \\
(0.0359)\end{array}$ \\
\hline Share of STEM graduates & $\begin{array}{c}0.0183 \\
(0.0156)\end{array}$ & $\begin{array}{c}0.0139 \\
(0.0182)\end{array}$ & $\begin{array}{c}0.0127 \\
(0.0186)\end{array}$ \\
\hline Share of part-time students & $\begin{array}{c}-0.0081 \\
(0.0159)\end{array}$ & $\begin{array}{c}-0.0093 \\
(0.0200)\end{array}$ & $\begin{array}{c}-0.0153 \\
(0.0212)\end{array}$ \\
\hline Year & $\begin{array}{l}-0.0011 \\
(0.0131)\end{array}$ & $\begin{array}{l}-0.0075 \\
(0.0203)\end{array}$ & $\begin{array}{l}-0.0128 \\
(0.0197)\end{array}$ \\
\hline Constant & $\begin{array}{c}-0.7899 * * * \\
(0.2019)\end{array}$ & $\begin{array}{c}-0.5516^{* *} \\
(0.2418)\end{array}$ & $\begin{array}{c}-0.5502 * * \\
(0.2490)\end{array}$ \\
\hline Number of non-HBCU years & 6962 & 6962 & 2497 \\
\hline Number of HBCU years & 432 & 432 & 432 \\
\hline
\end{tabular}

Notes: Standard errors in parentheses. ${ }^{* * *} \mathrm{p}<0.01, * * \mathrm{p}<0.05,{ }^{*} \mathrm{p}<0.1$. Weighted results use the inverse of the $\mathrm{p}$-score estimated from the first-stage probit estimation in the nearest-neighbor matching process. Matched sample created using 20 nearest-neighbor matches with replacement. Regression parameter estimates are available upon request; errors are clustered at the institution ID level in those regressions. Years of analysis are 2009 through 2018.

${ }^{a}$ Regressors not included in the first-stage probit estimated for construction of $\mathrm{p}$-score. 
Table 3. Decomposition of differences in log median debt load (\$2016, thousands), comparing HBCU and nonHBCU graduates.

\begin{tabular}{|c|c|c|c|}
\hline & $\begin{array}{c}\text { Unweighted } \\
\text { Sample }\end{array}$ & $\begin{array}{l}\text { Weighted } \\
\text { Sample }\end{array}$ & $\begin{array}{l}\text { Matched } \\
\text { Sample }\end{array}$ \\
\hline Average log median debt load non-HBCU graduates & $\begin{array}{l}9.9552 * * * \\
(0.0063)\end{array}$ & $\begin{array}{c}9.8828 * * * \\
(0.0193)\end{array}$ & $\begin{array}{c}9.8865 * * * \\
(0.0164)\end{array}$ \\
\hline Average log median debt load HBCU graduates & $\begin{array}{l}10.1808 * * * \\
(0.0240)\end{array}$ & $\begin{array}{l}10.1808 * * * \\
(0.0240)\end{array}$ & $\begin{array}{l}10.1808 * * * \\
(0.0240)\end{array}$ \\
\hline Observed log median debt load differential $\quad\left[\bar{Y}_{N}-\bar{Y}_{H}\right]=$ & $\begin{array}{c}-0.2256 * * * \\
(0.0248)\end{array}$ & $\begin{array}{c}-0.2980 * * * \\
(0.0308)\end{array}$ & $\begin{array}{c}-0.2942 * * * \\
(0.0291)\end{array}$ \\
\hline \multicolumn{4}{|l|}{ Contribution of differences in: } \\
\hline Characteristics $\quad\left(\overline{\mathrm{M}}_{N}-\overline{\mathrm{M}}_{H}\right)^{\prime}\left\{\boldsymbol{\Psi} \widehat{\Lambda}_{N}+(\boldsymbol{I}-\boldsymbol{\Psi}) \widehat{\Lambda}_{H}\right\}=$ & $\begin{array}{c}-0.1239 * * * \\
(0.0480)\end{array}$ & $\begin{array}{c}-0.0975 \\
(0.0964)\end{array}$ & $\begin{array}{c}-0.1506 * * \\
(0.0738)\end{array}$ \\
\hline Institutional characteristics & $\begin{array}{c}0.0877 * * * \\
(0.0093)\end{array}$ & $\begin{array}{c}0.0458 * * * \\
(0.0129)\end{array}$ & $\begin{array}{l}0.0461 * * * \\
(0.0131)\end{array}$ \\
\hline Endowment-expense ratio & $\begin{array}{c}-0.0196 * * * \\
(0.0050)\end{array}$ & $\begin{array}{l}-0.0003 \\
(0.0029)\end{array}$ & $\begin{array}{l}-0.0009 \\
(0.0040)\end{array}$ \\
\hline Revenue per fte - $\$ 1000$ s & $\begin{array}{l}-0.0045 \\
(0.0035)\end{array}$ & $\begin{array}{l}-0.0067 \\
(0.0086)\end{array}$ & $\begin{array}{l}-0.0082 \\
(0.0089)\end{array}$ \\
\hline In-state tuition and fees $-\$ 1000 \mathrm{~s}$ & $\begin{array}{c}0.1067 * * * \\
(0.0105)\end{array}$ & $\begin{array}{c}0.0530 * * * \\
(0.0128)\end{array}$ & $\begin{array}{c}0.0554 * * * \\
(0.0134)\end{array}$ \\
\hline Student to Faculty ratio & $\begin{array}{l}0.0045^{*} \\
(0.0024)\end{array}$ & $\begin{array}{c}0.0004 \\
(0.0039)\end{array}$ & $\begin{array}{l}-0.0002 \\
(0.0019)\end{array}$ \\
\hline Graduate program $=1$ & $\begin{array}{c}0.0005 \\
(0.0009)\end{array}$ & $\begin{array}{l}-0.0006 \\
(0.0023)\end{array}$ & $\begin{array}{l}-0.0000 \\
(0.0003)\end{array}$ \\
\hline Student body characteristics & $\begin{array}{c}-0.2122 * * * \\
(0.0465)\end{array}$ & $\begin{array}{l}-0.1432 \\
(0.0953)\end{array}$ & $\begin{array}{c}-0.1951 * * * \\
(0.0725)\end{array}$ \\
\hline Share of 1 st gen. college students & $\begin{array}{c}0.0296 * * * \\
(0.0073)\end{array}$ & $\begin{array}{c}0.0067 \\
(0.0112)\end{array}$ & $\begin{array}{c}0.0022 \\
(0.0078)\end{array}$ \\
\hline Share of undergrads who receive a Pell grant & $\begin{array}{c}0.0528 * * \\
(0.0248)\end{array}$ & $\begin{array}{c}-0.1146^{* *} \\
(0.0484)\end{array}$ & $\begin{array}{l}-0.0756^{*} \\
(0.0453)\end{array}$ \\
\hline Average SAT equivalent score of students admitted & $\begin{array}{c}-0.1556 * * * \\
(0.0198)\end{array}$ & $\begin{array}{l}-0.0401 \\
(0.0265)\end{array}$ & $\begin{array}{l}-0.0354 \\
(0.0259)\end{array}$ \\
\hline Share of female students & $\begin{array}{l}-0.0009 \\
(0.0015)\end{array}$ & $\begin{array}{c}0.0013 \\
(0.0031)\end{array}$ & $\begin{array}{l}-0.0001 \\
(0.0015)\end{array}$ \\
\hline Share of Non-Hispanic Black Students & $\begin{array}{c}-0.1197 * * \\
(0.0504)\end{array}$ & $\begin{array}{c}0.0245 \\
(0.1132)\end{array}$ & $\begin{array}{l}-0.0660 \\
(0.0836)\end{array}$ \\
\hline Share of STEM graduates & $\begin{array}{c}-0.0040 * * \\
(0.0019)\end{array}$ & $\begin{array}{l}-0.0007 \\
(0.0026)\end{array}$ & $\begin{array}{c}0.0003 \\
(0.0016)\end{array}$ \\
\hline Share of part-time students & $\begin{array}{c}-0.0143 * * * \\
(0.0037)\end{array}$ & $\begin{array}{l}-0.0202 \\
(0.0133)\end{array}$ & $\begin{array}{l}-0.0206 \\
(0.0133)\end{array}$ \\
\hline Year fixed effects & $\begin{array}{c}0.0006 \\
(0.0027)\end{array}$ & $\begin{array}{l}-0.0001 \\
(0.0022)\end{array}$ & $\begin{array}{l}-0.0016 \\
(0.0027)\end{array}$ \\
\hline
\end{tabular}




\begin{tabular}{|c|c|c|c|}
\hline & $\begin{array}{c}\text { Unweighted } \\
\text { Sample }\end{array}$ & $\begin{array}{l}\text { Weighted } \\
\text { Sample }\end{array}$ & $\begin{array}{l}\text { Matched } \\
\text { Sample }\end{array}$ \\
\hline Coefficients $\quad\left\{(\boldsymbol{I}-\boldsymbol{\Psi})^{\prime} \overline{\mathrm{M}}_{N}+\boldsymbol{\Psi}^{\prime} \overline{\mathrm{M}}_{H}\right\}\left(\widehat{\Lambda}_{N}-\widehat{\Lambda}_{H}\right)=$ & $\begin{array}{l}-0.1017 * \\
(0.0532)\end{array}$ & $\begin{array}{l}-0.2004 * \\
(0.1075)\end{array}$ & $\begin{array}{c}-0.1436 * \\
(0.0800)\end{array}$ \\
\hline Institutional characteristics & $\begin{array}{l}-0.1527 \\
(0.1245)\end{array}$ & $\begin{array}{c}-0.3467 * * \\
(0.1520)\end{array}$ & $\begin{array}{l}-0.2548^{*} \\
(0.1406)\end{array}$ \\
\hline Endowment-expense ratio & $\begin{array}{c}0.0166 \\
(0.0150)\end{array}$ & $\begin{array}{c}0.0385 * * \\
(0.0180)\end{array}$ & $\begin{array}{l}0.0330^{*} \\
(0.0182)\end{array}$ \\
\hline Revenue per fte - $\$ 1000$ s & $\begin{array}{c}0.0065 \\
(0.0503)\end{array}$ & $\begin{array}{l}-0.0140 \\
(0.0517)\end{array}$ & $\begin{array}{l}-0.0079 \\
(0.0520)\end{array}$ \\
\hline In-state tuition and fees $-\$ 1000 \mathrm{~s}$ & $\begin{array}{c}0.0032 \\
(0.0469)\end{array}$ & $\begin{array}{l}-0.0021 \\
(0.0505)\end{array}$ & $\begin{array}{l}0.0040 \\
(0.0500)\end{array}$ \\
\hline Student to Faculty ratio & $\begin{array}{l}-0.1877^{*} \\
(0.1110)\end{array}$ & $\begin{array}{c}-0.3971 * * * \\
(0.1389)\end{array}$ & $\begin{array}{c}-0.2947 * * \\
(0.1244)\end{array}$ \\
\hline Graduate program $=1$ & $\begin{array}{c}0.0087 \\
(0.0254)\end{array}$ & $\begin{array}{c}0.0280 \\
(0.0312)\end{array}$ & $\begin{array}{c}0.0108 \\
(0.0286)\end{array}$ \\
\hline Student body characteristics & $\begin{array}{c}-0.6411 * * \\
(0.3197)\end{array}$ & $\begin{array}{l}-0.3905 \\
(0.4233)\end{array}$ & $\begin{array}{l}-0.1825 \\
(0.3932)\end{array}$ \\
\hline Share of 1st gen. college students & $\begin{array}{c}0.1182 \\
(0.1840)\end{array}$ & $\begin{array}{l}-0.0027 \\
(0.1994)\end{array}$ & $\begin{array}{c}0.1154 \\
(0.1957)\end{array}$ \\
\hline Share of undergrads who receive a Pell grant & $\begin{array}{l}-0.4305 * * * \\
(0.1290)\end{array}$ & $\begin{array}{l}-0.1773 \\
(0.1188)\end{array}$ & $\begin{array}{c}-0.2964 * * * \\
(0.1132)\end{array}$ \\
\hline Average SAT equivalent score of students admitted & $\begin{array}{c}-0.6134 * * * \\
(0.2165)\end{array}$ & $\begin{array}{l}-0.2823 \\
(0.2985)\end{array}$ & $\begin{array}{l}-0.2634 \\
(0.2845)\end{array}$ \\
\hline Share of female students & $\begin{array}{c}0.0299 \\
(0.1153)\end{array}$ & $\begin{array}{l}-0.0139 \\
(0.1355)\end{array}$ & $\begin{array}{c}0.0603 \\
(0.1314)\end{array}$ \\
\hline Share of Non-Hispanic Black Students & $\begin{array}{c}0.0440 \\
(0.1290)\end{array}$ & $\begin{array}{l}-0.1382 \\
(0.1592)\end{array}$ & $\begin{array}{l}-0.0253 \\
(0.1185)\end{array}$ \\
\hline Share of STEM graduates & $\begin{array}{c}0.1345 * * * \\
(0.0384)\end{array}$ & $\begin{array}{c}0.1138 * * * \\
(0.0421)\end{array}$ & $\begin{array}{c}0.1276^{* * *} \\
(0.0413)\end{array}$ \\
\hline Share of part-time students & $\begin{array}{l}0.0762 * \\
(0.0433)\end{array}$ & $\begin{array}{c}0.1099 * * \\
(0.0512)\end{array}$ & $\begin{array}{l}0.0993 * \\
(0.0507)\end{array}$ \\
\hline Year & $\begin{array}{c}0.0143 \\
(0.0262)\end{array}$ & $\begin{array}{l}-0.0428 \\
(0.0320)\end{array}$ & $\begin{array}{l}-0.0311 \\
(0.0296)\end{array}$ \\
\hline Constant & $\begin{array}{c}0.6778 * * \\
(0.3302)\end{array}$ & $\begin{array}{c}0.5796 \\
(0.4303)\end{array}$ & $\begin{array}{c}0.3248 \\
(0.3983)\end{array}$ \\
\hline $\begin{array}{l}\text { Number of non-HBCU years } \\
\text { Number of HBCU years }\end{array}$ & $\begin{array}{c}6993 \\
420\end{array}$ & $\begin{array}{c}6993 \\
420\end{array}$ & $\begin{array}{c}2615 \\
420\end{array}$ \\
\hline
\end{tabular}

Notes: Standard errors in parentheses. ${ }^{* * *} \mathrm{p}<0.01, * * \mathrm{p}<0.05, * \mathrm{p}<0.1$. Weighted results use the inverse of the $\mathrm{p}$-score estimated from the first-stage probit estimation in the nearest-neighbor matching process. Matched sample created using between 1 and 20 nearest-neighbor matches with replacement. Regression parameter estimates are available upon request; errors are clustered at the institution ID level in those regressions. Years of analysis are 2009 through 2018.

${ }^{a}$ Regressors not included in the first-stage probit estimated for construction of $\mathrm{p}$-score. 
Table 4. Decomposition of differences in log median annual earnings ( $\$ 2016$, thousands) 10 years after matriculation, comparing HBCU and non-HBCU graduates

\begin{tabular}{|c|c|c|c|}
\hline & $\begin{array}{c}\text { Unweighted } \\
\text { Sample }\end{array}$ & $\begin{array}{l}\text { Weighted } \\
\text { Sample }\end{array}$ & $\begin{array}{l}\text { Matched } \\
\text { Sample }\end{array}$ \\
\hline Median log annual earnings non-HBCU graduates & $\begin{array}{l}10.7030 * * * \\
(0.0064)\end{array}$ & $\begin{array}{l}10.6624 * * * \\
(0.0169)\end{array}$ & $\begin{array}{c}10.6585 * * * \\
(0.0168)\end{array}$ \\
\hline Median log annual earnings HBCU graduates & $\begin{array}{l}10.3900 * * * \\
(0.0202)\end{array}$ & $\begin{array}{c}10.3900 * * * \\
(0.0202)\end{array}$ & $\begin{array}{c}10.3900 * * * \\
(0.0202)\end{array}$ \\
\hline Observed median log earnings differential $\quad\left[\bar{Y}_{N}-\bar{Y}_{H}\right]=$ & $\begin{array}{c}0.3129 * * * \\
(0.0212)\end{array}$ & $\begin{array}{c}0.2724 * * * \\
(0.0263)\end{array}$ & $\begin{array}{c}0.2685 * * * \\
(0.0262)\end{array}$ \\
\hline \multicolumn{4}{|l|}{ Contribution of differences in: } \\
\hline Characteristics $\quad\left(\overline{\mathrm{M}}_{N}-\overline{\mathrm{M}}_{H}\right)^{\prime}\left\{\boldsymbol{\Psi} \widehat{\Lambda}_{N}+(\boldsymbol{I}-\boldsymbol{\Psi}) \widehat{\Lambda}_{H}\right\}=$ & $\begin{array}{c}0.1986 * * * \\
(0.0270)\end{array}$ & $\begin{array}{c}0.1543 * * * \\
(0.0319)\end{array}$ & $\begin{array}{c}0.1758 * * * \\
(0.0358)\end{array}$ \\
\hline Institutional characteristics & $\begin{array}{l}0.0785 * * * \\
(0.0090)\end{array}$ & $\begin{array}{c}0.0271 * * \\
(0.0107)\end{array}$ & $\begin{array}{l}0.0284 * * \\
(0.0113)\end{array}$ \\
\hline Endowment-expense ratio & $\begin{array}{l}-0.0077 * * * \\
(0.0025)\end{array}$ & $\begin{array}{c}0.0000 \\
(0.0005)\end{array}$ & $\begin{array}{l}-0.0000 \\
(0.0009)\end{array}$ \\
\hline Revenue per fte - $\$ 1000 \mathrm{~s}$ & $\begin{array}{l}0.0021^{*} \\
(0.0012)\end{array}$ & $\begin{array}{c}0.0008 \\
(0.0014)\end{array}$ & $\begin{array}{c}0.0002 \\
(0.0009)\end{array}$ \\
\hline In-state tuition and fees $-\$ 1000 \mathrm{~s}^{\mathrm{a}}$ & $\begin{array}{c}0.0832 * * * \\
(0.0089)\end{array}$ & $\begin{array}{c}0.0276 * * * \\
(0.0093)\end{array}$ & $\begin{array}{c}0.0283 * * * \\
(0.0099)\end{array}$ \\
\hline Student to Faculty ratio & $\begin{array}{l}-0.0040^{*} \\
(0.0024)\end{array}$ & $\begin{array}{c}0.0000 \\
(0.0011)\end{array}$ & $\begin{array}{l}-0.0001 \\
(0.0004)\end{array}$ \\
\hline Graduate program $=1$ & $\begin{array}{c}0.0050 \\
(0.0050)\end{array}$ & $\begin{array}{l}-0.0014 \\
(0.0057)\end{array}$ & $\begin{array}{c}0.0000 \\
(0.0062)\end{array}$ \\
\hline Student body characteristics & $\begin{array}{c}0.1209 * * * \\
(0.0245)\end{array}$ & $\begin{array}{c}0.1274 * * * \\
(0.0287)\end{array}$ & $\begin{array}{c}0.1487 * * * \\
(0.0330)\end{array}$ \\
\hline Share of 1 st gen. college students & $\begin{array}{c}-0.0170 * * * \\
(0.0052)\end{array}$ & $\begin{array}{c}0.0001 \\
(0.0011)\end{array}$ & $\begin{array}{l}-0.0001 \\
(0.0007)\end{array}$ \\
\hline Share of undergrads who receive a Pell grant ${ }^{\mathrm{a}}$ & $\begin{array}{l}0.1796 * * * \\
(0.0184)\end{array}$ & $\begin{array}{c}0.1445 * * * \\
(0.0237)\end{array}$ & $\begin{array}{c}0.1486 * * * \\
(0.0253)\end{array}$ \\
\hline Average SAT equivalent score of students admitted ${ }^{\mathrm{a}}$ & $\begin{array}{c}0.0636 * * * \\
(0.0152)\end{array}$ & $\begin{array}{c}0.0592 * * * \\
(0.0224)\end{array}$ & $\begin{array}{c}0.0704 * * * \\
(0.0228)\end{array}$ \\
\hline Share of female students & $\begin{array}{c}0.0028 \\
(0.0023)\end{array}$ & $\begin{array}{c}0.0015 \\
(0.0030)\end{array}$ & $\begin{array}{c}0.0009 \\
(0.0028)\end{array}$ \\
\hline Share of Non-Hispanic Black Students ${ }^{\mathrm{a}}$ & $\begin{array}{c}-0.1017 * * * \\
(0.0271)\end{array}$ & $\begin{array}{c}-0.0763 * * \\
(0.0380)\end{array}$ & $\begin{array}{l}-0.0685 \\
(0.0433)\end{array}$ \\
\hline Share of STEM graduates & $\begin{array}{c}-0.0087 * * \\
(0.0040)\end{array}$ & $\begin{array}{c}0.0038 \\
(0.0043)\end{array}$ & $\begin{array}{c}0.0008 \\
(0.0037)\end{array}$ \\
\hline Share of part-time students ${ }^{\mathrm{a}}$ & $\begin{array}{c}0.0022 \\
(0.0025)\end{array}$ & $\begin{array}{l}-0.0054 \\
(0.0116)\end{array}$ & $\begin{array}{l}-0.0034 \\
(0.0114)\end{array}$ \\
\hline Year fixed effects & $\begin{array}{l}-0.0009 \\
(0.0008)\end{array}$ & $\begin{array}{l}-0.0001 \\
(0.0010)\end{array}$ & $\begin{array}{l}-0.0014 \\
(0.0011)\end{array}$ \\
\hline
\end{tabular}




\begin{tabular}{|c|c|c|c|}
\hline & $\begin{array}{c}\text { Unweighted } \\
\text { Sample }\end{array}$ & $\begin{array}{l}\text { Weighted } \\
\text { Sample }\end{array}$ & $\begin{array}{l}\text { Matched } \\
\text { Sample }\end{array}$ \\
\hline Coefficients $\quad\left\{(\boldsymbol{I}-\boldsymbol{\Psi})^{\prime} \overline{\mathrm{M}}_{N}+\boldsymbol{\Psi}^{\prime} \overline{\mathrm{M}}_{H}\right\}\left(\widehat{\Lambda}_{N}-\widehat{\Lambda}_{H}\right)=$ & $\begin{array}{c}0.1144 * * * \\
(0.0269)\end{array}$ & $\begin{array}{c}0.1181 * * * \\
(0.0307)\end{array}$ & $\begin{array}{c}0.0927 * * * \\
(0.0345)\end{array}$ \\
\hline Institutional characteristics & $\begin{array}{c}0.0551 \\
(0.0705)\end{array}$ & $\begin{array}{c}0.0336 \\
(0.1049)\end{array}$ & $\begin{array}{l}-0.0257 \\
(0.1070)\end{array}$ \\
\hline Endowment-expense ratio & $\begin{array}{c}-0.0326 * * * \\
(0.0099)\end{array}$ & $\begin{array}{c}-0.0409 * * * \\
(0.0117)\end{array}$ & $\begin{array}{c}-0.0393 * * * \\
(0.0121)\end{array}$ \\
\hline Revenue per fte $-\$ 1000$ s & $\begin{array}{l}-0.0163 \\
(0.0249)\end{array}$ & $\begin{array}{l}-0.0162 \\
(0.0260)\end{array}$ & $\begin{array}{l}-0.0254 \\
(0.0262)\end{array}$ \\
\hline In-state tuition and fees $-\$ 1000 \mathrm{~s}^{\mathrm{a}}$ & $\begin{array}{l}0.0490 * \\
(0.0291)\end{array}$ & $\begin{array}{c}0.0719 * * \\
(0.0323)\end{array}$ & $\begin{array}{l}0.0638 * \\
(0.0332)\end{array}$ \\
\hline Student to Faculty ratio & $\begin{array}{c}0.0840 \\
(0.0676)\end{array}$ & $\begin{array}{c}0.0666 \\
(0.0927)\end{array}$ & $\begin{array}{c}0.0187 \\
(0.0942)\end{array}$ \\
\hline Graduate program $=1$ & $\begin{array}{l}-0.0289 \\
(0.0186)\end{array}$ & $\begin{array}{c}-0.0479 * * \\
(0.0209)\end{array}$ & $\begin{array}{c}-0.0436 * * \\
(0.0213)\end{array}$ \\
\hline Student body characteristics & $\begin{array}{l}-0.0222 \\
(0.2682)\end{array}$ & $\begin{array}{l}-0.3503 \\
(0.3802)\end{array}$ & $\begin{array}{l}-0.1975 \\
(0.3939)\end{array}$ \\
\hline Share of 1 st gen. college students & $\begin{array}{l}0.1514 * * \\
(0.0759)\end{array}$ & $\begin{array}{c}0.0434 \\
(0.1017)\end{array}$ & $\begin{array}{c}0.1026 \\
(0.1112)\end{array}$ \\
\hline Share of undergrads who receive a Pell grant ${ }^{\mathrm{a}}$ & $\begin{array}{l}-0.0507 \\
(0.0880)\end{array}$ & $\begin{array}{c}0.0418 \\
(0.0915)\end{array}$ & $\begin{array}{c}0.0049 \\
(0.0987)\end{array}$ \\
\hline Average SAT equivalent score of students admitted ${ }^{\mathrm{a}}$ & $\begin{array}{l}-0.2387 \\
(0.1741)\end{array}$ & $\begin{array}{l}-0.3253 \\
(0.2394)\end{array}$ & $\begin{array}{l}-0.2172 \\
(0.2515)\end{array}$ \\
\hline Share of female students & $\begin{array}{l}-0.0881 \\
(0.0565)\end{array}$ & $\begin{array}{c}-0.2514 * * \\
(0.1149)\end{array}$ & $\begin{array}{c}-0.2285 * * \\
(0.1127)\end{array}$ \\
\hline Share of Non-Hispanic Black Students ${ }^{\mathrm{a}}$ & $\begin{array}{c}0.0866 \\
(0.0749)\end{array}$ & $\begin{array}{c}0.0600 \\
(0.0673)\end{array}$ & $\begin{array}{c}0.0511 \\
(0.0678)\end{array}$ \\
\hline Share of STEM graduates & $\begin{array}{c}0.0933 * * * \\
(0.0209)\end{array}$ & $\begin{array}{c}0.0621 * * \\
(0.0254)\end{array}$ & $\begin{array}{c}0.0650 * * * \\
(0.0251)\end{array}$ \\
\hline Share of part-time students ${ }^{\mathrm{a}}$ & $\begin{array}{c}0.0239 \\
(0.0195)\end{array}$ & $\begin{array}{c}0.0190 \\
(0.0257)\end{array}$ & $\begin{array}{c}0.0247 \\
(0.0269)\end{array}$ \\
\hline Year & $\begin{array}{c}0.0702 * * * \\
(0.0171)\end{array}$ & $\begin{array}{c}0.0956 * * * \\
(0.0179)\end{array}$ & $\begin{array}{c}0.0795 * * * \\
(0.0189)\end{array}$ \\
\hline Constant & $\begin{array}{c}0.0113 \\
(0.2917)\end{array}$ & $\begin{array}{c}0.3392 \\
(0.4348)\end{array}$ & $\begin{array}{c}0.2364 \\
(0.4514)\end{array}$ \\
\hline Number of non-HBCU years & 3706 & 3706 & 1373 \\
\hline Number of HBCU years & 232 & 232 & 232 \\
\hline
\end{tabular}

Notes: Standard errors in parentheses. ${ }^{* * *} \mathrm{p}<0.01, * * \mathrm{p}<0.05,{ }^{*} \mathrm{p}<0.1$. Weighted results use the inverse of the $\mathrm{p}$-score estimated from the first-stage probit estimation in the nearest-neighbor matching process. Matched sample created using between 1 and 20 nearest-neighbor matches with replacement. Regression parameter estimates are available upon request; errors are clustered at the institution ID level in those regressions. Years of analysis are 2010 and 2012 through 2015.

${ }^{a}$ Regressors not included in the first-stage probit estimated for construction of $\mathrm{p}$-score. 


\section{Appendix A. Estimating Sample Means.}

Table A1 Estimating sample means for HBCU and non-HBCU graduates, Black 6-year graduation rate.

\begin{tabular}{|c|c|c|c|c|}
\hline \multirow[b]{2}{*}{ Individual Characteristics } & \multirow[b]{2}{*}{$\mathrm{HBCU}$} & \multicolumn{3}{|c|}{ non-HBCU } \\
\hline & & Unweighted & Weighted & Matched \\
\hline \multicolumn{5}{|l|}{ Outcome measures } \\
\hline \multirow{2}{*}{ 6-year Black graduation rate } & .3429 & $.4223^{*}$ & .3319 & $.3263^{\wedge}$ \\
\hline & {$[.1308]$} & {$[.2285]$} & {$[.2095]$} & {$[.2065]$} \\
\hline \multicolumn{5}{|l|}{ Institutional Characteristics } \\
\hline \multirow[t]{2}{*}{ Endowment-expense ratio } & .4473 & $1.0351^{*}$ & .4543 & .47 \\
\hline & {$[.5916]$} & {$[1.5582]$} & {$[.5897]$} & {$[.6182]$} \\
\hline \multirow[t]{2}{*}{ Revenue per fte - $\$ 1000$ s } & 28.7915 & $31.283^{*}$ & $31.5279^{*}$ & $31.2864^{\wedge}$ \\
\hline & {$[11.2855]$} & [36.3445] & {$[48.688]$} & {$[48.5746]$} \\
\hline \multirow[t]{2}{*}{ In-state tuition and fees $-\$ 1000 \mathrm{~s}$} & 10.3126 & $22.2978^{*}$ & $15.1876^{*}$ & $15.3069^{*}$ \\
\hline & {$[5.7964]$} & {$[12.5831]$} & {$[10.8916]$} & {$[10.8651]$} \\
\hline \multirow[t]{2}{*}{ Student to Faculty ratio } & 15.2731 & $14.3743^{*}$ & 15.2591 & 15.3618 \\
\hline & {$[3.0003]$} & {$[3.8166]$} & {$[3.954]$} & {$[3.9754]$} \\
\hline \multirow[t]{2}{*}{ Graduate program $=1$} & .5278 & $.5991^{*}$ & .5152 & .5292 \\
\hline & {$[.4998]$} & {$[.4901]$} & [.4998] & [.4992] \\
\hline \multicolumn{5}{|l|}{ Student Characteristics } \\
\hline \multirow[t]{2}{*}{ Share of 1 st gen. college students } & 38.8838 & $32.8106^{*}$ & $38.2302^{+}$ & 38.7836 \\
\hline & [7.9084] & [10.2811] & [9.5197] & {$[9.1088]$} \\
\hline \multirow[t]{2}{*}{ Share of undergrads who receive a Pell grant } & 65.04 & $32.4505^{*}$ & $38.2276^{*}$ & $38.3453^{*}$ \\
\hline & {$[14.0303]$} & [12.4997] & {$[13.2184]$} & {$[12.9671]$} \\
\hline \multirow[t]{2}{*}{ Avg SAT equiv. score of students admitted } & 867.0463 & $1063.916^{*}$ & $1016.194^{*}$ & $1012.288^{*}$ \\
\hline & {$[81.0746]$} & [119.6406] & {$[107.84]$} & {$[106.6734]$} \\
\hline \multirow[t]{2}{*}{ Share of female students } & 60.8713 & $58.1232^{*}$ & $59.3303^{\wedge}$ & 59.9639 \\
\hline & {$[12.1032]$} & [11.9819] & {$[16.9432]$} & [16.9639] \\
\hline \multirow[t]{2}{*}{ Share of Non-Hispanic Black Students } & 82.4828 & $9.8609^{*}$ & $13.5358^{*}$ & $12.733^{*}$ \\
\hline & {$[17.164]$} & {$[9.2825]$} & {$[14.4845]$} & {$[12.2554]$} \\
\hline \multirow[t]{2}{*}{ Share of STEM graduates } & 15.7783 & $13.2202^{*}$ & $17.8636^{*}$ & $17.1075^{\wedge}$ \\
\hline & {$[7.4841]$} & [13.2724] & {$[20.7722]$} & [20.5775] \\
\hline \multirow[t]{2}{*}{ Share of part-time students ${ }^{a}$} & 14.2178 & $22.067^{*}$ & $27.3276^{*}$ & $27.7958^{*}$ \\
\hline & [9.6739] & [14.8989] & {$[15.1691]$} & [15.2117] \\
\hline Observations & 432 & 6962 & 6962 & 2497 \\
\hline
\end{tabular}

Notes: Standard deviations in brackets. Weighted means use the inverse of the p-score estimated from a firststage probit estimation in the nearest-neighbor matching process. Matched sample results from 20 nearestneighbor matches with replacement. ${ }^{*},{ }^{\wedge},{ }^{+}=>$mean is statistically significantly different from the HBCU sample mean at the $99 \%, 95 \%$, and $90 \%$ confidence level. 
Table A2 Sample means between HBCU and non-HBCU graduates, median debt load analysis.

\begin{tabular}{|c|c|c|c|c|}
\hline \multirow[b]{2}{*}{ Individual Characteristics } & \multirow[b]{2}{*}{ HBCU } & \multicolumn{3}{|c|}{ non-HBCU } \\
\hline & & Unweighted & Weighted & Matched \\
\hline \multicolumn{5}{|l|}{ Outcome measures } \\
\hline Median debt load of graduates & 10.1808 & $9.9552^{*}$ & $9.8828^{*}$ & $9.8865^{*}$ \\
\hline (\$2016, thousands) & {$[.2393]$} & {$[.2353]$} & {$[.2947]$} & {$[.2742]$} \\
\hline \multicolumn{5}{|l|}{ Institutional Characteristics } \\
\hline \multirow[t]{2}{*}{ Endowment-expense ratio } & .4456 & $1.0253^{*}$ & .4533 & .4639 \\
\hline & {$[.5977]$} & {$[1.5462]$} & {$[.6007]$} & {$[.625]$} \\
\hline \multirow[t]{2}{*}{ Revenue per fte - $\$ 1000$ s } & 28.9281 & $31.239^{*}$ & $31.6925^{*}$ & $32.693^{*}$ \\
\hline & {$[11.3943]$} & [36.3024] & {$[50.3845]$} & {$[54.9644]$} \\
\hline \multirow[t]{2}{*}{ In-state tuition and fees $-\$ 1000$ s } & 10.3148 & $22.1889^{*}$ & $15.1829^{*}$ & $15.2187^{*}$ \\
\hline & {$[5.8614]$} & [12.6214] & {$[10.9425]$} & {$[10.9905]$} \\
\hline \multirow[t]{2}{*}{ Student to Faculty ratio } & 15.3143 & $14.3912^{*}$ & 15.2754 & 15.3532 \\
\hline & {$[3.0236]$} & {$[3.8604]$} & [3.9863] & {$[3.9874]$} \\
\hline \multirow[t]{2}{*}{ Graduate program $=1$} & .5333 & $.5949^{\wedge}$ & .5133 & .5231 \\
\hline & {$[.4995]$} & [.491] & [.4999] & {$[.4996]$} \\
\hline \multicolumn{5}{|l|}{ Student Characteristics } \\
\hline \multirow[t]{2}{*}{ Share of 1 st gen. college students } & 38.7416 & $32.8362^{*}$ & $37.9883^{+}$ & 38.4061 \\
\hline & {$[7.9485]$} & {$[10.311]$} & {$[9.6474]$} & {$[9.3573]$} \\
\hline \multirow{2}{*}{ Share of undergrads who receive a Pell grant } & 65.2624 & $32.5282^{*}$ & $38.1626^{*}$ & $38.0703^{*}$ \\
\hline & {$[13.7732]$} & {$[12.5508]$} & {$[13.1531]$} & {$[13.0732]$} \\
\hline \multirow[t]{2}{*}{ Avg SAT equiv. score of students admitted } & 868.2619 & $1063.212^{*}$ & $1015.67^{*}$ & $1015.004^{*}$ \\
\hline & {$[81.3778]$} & {$[119.9396]$} & {$[109.4403]$} & [110.6432] \\
\hline \multirow[t]{2}{*}{ Share of female students } & 60.8828 & $58.1533^{*}$ & $59.3669^{\wedge}$ & 59.8683 \\
\hline & {$[12.2834]$} & [11.9758] & {$[16.4795]$} & {$[16.9089]$} \\
\hline \multirow[t]{2}{*}{ Share of Non-Hispanic Black Students } & 82.4366 & $9.8615^{*}$ & $13.3819^{*}$ & $12.7645^{*}$ \\
\hline & {$[17.2382]$} & [9.3209] & {$[14.2155]$} & {$[12.8609]$} \\
\hline \multirow[t]{2}{*}{ Share of STEM graduates } & 15.9004 & $13.2655^{*}$ & $18.0528^{*}$ & $17.3574^{*}$ \\
\hline & {$[7.5238]$} & [13.3165] & [20.6889] & {$[20.4174]$} \\
\hline \multirow[t]{2}{*}{ Share of part-time students ${ }^{a}$} & 14.2972 & $22.2272^{*}$ & $27.7084^{*}$ & $28.0952^{*}$ \\
\hline & {$[9.8428]$} & [14.9766] & {$[15.1802]$} & {$[15.4196]$} \\
\hline Observations & 420 & 6993 & 6993 & 2615 \\
\hline
\end{tabular}

Notes: Standard deviations in brackets. Weighted means use the inverse of the p-score estimated from a firststage probit estimation in the nearest-neighbor matching process. Matched sample results from 20 nearestneighbor matches with replacement. ${ }^{*},{ }^{\wedge},{ }^{+}=>$mean is statistically significantly different from the HBCU sample mean at the $99 \%, 95 \%$, and $90 \%$ confidence level. 
Table A3 Sample means between HBCU and non-HBCU graduates, log median annual earnings 10 years after matriculation analysis.

\begin{tabular}{|c|c|c|c|c|}
\hline \multirow[b]{2}{*}{ Individual Characteristics } & \multirow[b]{2}{*}{$\mathrm{HBCU}$} & \multicolumn{3}{|c|}{ non-HBCU } \\
\hline & & Unweighted & Weighted & Matched \\
\hline \multicolumn{5}{|l|}{ Outcome measures } \\
\hline Earnings $10 y$ rs after matriculation & 10.39 & $10.703^{*}$ & $10.6624^{*}$ & $10.6585^{*}$ \\
\hline (\$2016, thousands) & {$[.1703]$} & {$[.2007]$} & {$[.2246]$} & {$[.2202]$} \\
\hline \multicolumn{5}{|l|}{ Institutional Characteristics } \\
\hline \multirow[t]{2}{*}{ Endowment-expense ratio } & .4447 & $1.0702^{*}$ & .4492 & .4428 \\
\hline & {$[.6019]$} & {$[1.623]$} & {$[.5795]$} & {$[.559]$} \\
\hline \multirow{2}{*}{ Revenue per fte - $\$ 1000$ s } & 28.7396 & $32.0335^{*}$ & $30.8125^{\wedge}$ & $32.1021^{\wedge}$ \\
\hline & {$[10.9384]$} & {$[36.2611]$} & {$[44.1562]$} & [48.4136] \\
\hline \multirow[t]{2}{*}{ In-state tuition and fees $-\$ 1000 \mathrm{~s}$} & 10.2809 & $22.1014^{*}$ & $15.0442^{*}$ & $15.4007^{*}$ \\
\hline & {$[5.838]$} & [12.6591] & {$[10.8224]$} & {$[10.8985]$} \\
\hline \multirow[t]{2}{*}{ Student to Faculty ratio } & 15.3103 & $14.4158^{*}$ & 15.3134 & 15.2442 \\
\hline & {$[2.8495]$} & {$[3.8525]$} & [3.8683] & {$[3.8523]$} \\
\hline \multirow[t]{2}{*}{ Graduate program $=1$} & .5259 & $.5961^{\wedge}$ & .5071 & .5261 \\
\hline & {$[.5004]$} & {$[.4908]$} & {$[.5]$} & {$[.4995]$} \\
\hline \multicolumn{5}{|l|}{ Student Characteristics } \\
\hline \multirow[t]{2}{*}{ Share of 1 st gen. college students } & 39.0166 & $32.7891^{*}$ & 38.3675 & 38.7235 \\
\hline & {$[7.6748]$} & {$[10.3546]$} & {$[9.4731]$} & {$[9.1542]$} \\
\hline \multirow[t]{2}{*}{ Share of undergrads who receive a Pell grant } & 67.0475 & $33.5899^{*}$ & $39.7388^{*}$ & $39.6596^{*}$ \\
\hline & {$[12.6312]$} & [12.5343] & {$[13.0588]$} & [12.5299] \\
\hline \multirow[t]{2}{*}{ Avg SAT equiv. score of students admitted } & 863.5905 & $1065.665^{*}$ & $1013.151^{*}$ & $1011.954^{*}$ \\
\hline & {$[73.161]$} & [121.3641] & [109.9307] & [109.9579] \\
\hline \multirow[t]{2}{*}{ Share of female students } & 60.5225 & $57.8691^{*}$ & 59.3336 & 59.8099 \\
\hline & {$[12.112]$} & [11.9667] & {$[16.878]$} & {$[16.7145]$} \\
\hline \multirow[t]{2}{*}{ Share of Non-Hispanic Black Students } & 82.6647 & $9.8518^{*}$ & $13.5321^{*}$ & $12.8693^{*}$ \\
\hline & {$[16.9068]$} & {$[9.4305]$} & [14.7092] & {$[12.2658]$} \\
\hline \multirow[t]{2}{*}{ Share of STEM graduates } & 15.6038 & $13.3455^{*}$ & $17.4683^{*}$ & 15.9981 \\
\hline & [7.4609] & [13.2197] & {$[20.497]$} & {$[19.1153]$} \\
\hline \multirow[t]{2}{*}{ Share of part-time students } & 13.9929 & $21.9153^{*}$ & $28.003^{*}$ & $28.7388^{*}$ \\
\hline & {$[8.8971]$} & [14.9072] & {$[15.089]$} & {$[15.6357]$} \\
\hline Observations & 232 & 3706 & 3706 & 1373 \\
\hline
\end{tabular}

Notes: Standard deviations in brackets. Weighted means use the inverse of the p-score estimated from a firststage probit estimation in the nearest-neighbor matching process. Matched sample results from 20 nearestneighbor matches with replacement. ${ }^{*},{ }^{\wedge},{ }^{+} \Rightarrow$ mean is statistically significantly different from the HBCU sample mean at the $99 \%, 95 \%$, and $90 \%$ confidence level. 


\section{Appendix B. First-stage Probit Results Used for Constructing p-scores.}

Table B1 Probit estimates of institution being a HBCU; outcomes samples included in paper.

\begin{tabular}{|c|c|c|c|}
\hline Regressors & $\begin{array}{c}\text { Graduate Rate } \\
\text { Sample }\end{array}$ & $\begin{array}{c}\text { Debt Load } \\
\text { Sample }\end{array}$ & $\begin{array}{c}\text { Median } \\
\text { Earnings } 10 \\
\text { Years Out } \\
\text { Sample }\end{array}$ \\
\hline \multicolumn{4}{|l|}{ Institutional Characteristics } \\
\hline Endowment-expense ratio & $\begin{array}{c}-0.3264 * * * \\
(0.0548)\end{array}$ & $\begin{array}{c}-0.3083 * * * \\
(0.0538)\end{array}$ & $\begin{array}{c}-0.3149 * * * \\
(0.0732)\end{array}$ \\
\hline Revenue per fte - $\$ 1000$ s & $\begin{array}{c}0.0085 * * * \\
(0.0010)\end{array}$ & $\begin{array}{c}0.0083 * * * \\
(0.0010)\end{array}$ & $\begin{array}{c}0.0086 * * * \\
(0.0014)\end{array}$ \\
\hline Student to Faculty ratio & $\begin{array}{c}0.0116 \\
(0.0103)\end{array}$ & $\begin{array}{c}0.0117 \\
(0.0102)\end{array}$ & $\begin{array}{c}0.0058 \\
(0.0144)\end{array}$ \\
\hline Graduate program $=1$ & $\begin{array}{c}-0.2353 * * * \\
(0.0677)\end{array}$ & $\begin{array}{c}-0.1925 * * * \\
(0.0677)\end{array}$ & $\begin{array}{c}-0.1929 * * \\
(0.0913)\end{array}$ \\
\hline \multicolumn{4}{|l|}{ Student Characteristics } \\
\hline Share of 1st gen. college students & $\begin{array}{c}0.0270 * * * \\
(0.0038)\end{array}$ & $\begin{array}{c}0.0264 * * * \\
(0.0038)\end{array}$ & $\begin{array}{c}0.0304 * * * \\
(0.0053)\end{array}$ \\
\hline Share of female students & $\begin{array}{c}0.0162 * * * \\
(0.0026)\end{array}$ & $\begin{array}{c}0.0156 * * * \\
(0.0026)\end{array}$ & $\begin{array}{c}0.0146 * * * \\
(0.0035)\end{array}$ \\
\hline Share of STEM graduates & $\begin{array}{c}0.0195 * * * \\
(0.0024)\end{array}$ & $\begin{array}{c}0.0187 * * * \\
(0.0024)\end{array}$ & $\begin{array}{c}0.0191 * * * \\
(0.0033)\end{array}$ \\
\hline \multicolumn{4}{|c|}{ Regressors Unique to first-stage Probit } \\
\hline Size $1,000-4,999$ & $\begin{array}{c}-0.5080 * * * \\
(0.1057)\end{array}$ & $\begin{array}{c}-0.4593 * * * \\
(0.1050)\end{array}$ & $\begin{array}{c}-0.3601 * * \\
(0.1479)\end{array}$ \\
\hline Size 5,000-9,999 & $\begin{array}{c}-1.1568 * * * \\
(0.1392)\end{array}$ & $\begin{array}{c}-1.0718 * * * \\
(0.1377)\end{array}$ & $\begin{array}{c}-1.0625 * * * \\
(0.1918)\end{array}$ \\
\hline Size 10,000-19,999 & $\begin{array}{c}-2.1421 * * * \\
(0.1728)\end{array}$ & $\begin{array}{c}-2.0238 * * * \\
(0.1716)\end{array}$ & $\begin{array}{c}-1.9190 * * * \\
(0.2315)\end{array}$ \\
\hline City: midsize & $\begin{array}{c}-0.1770 * * \\
(0.0845)\end{array}$ & $\begin{array}{l}-0.1426^{*} \\
(0.0845)\end{array}$ & $\begin{array}{l}-0.1678 \\
(0.1151)\end{array}$ \\
\hline City: small & $\begin{array}{c}-0.8150 * * * \\
(0.1013)\end{array}$ & $\begin{array}{c}-0.7950^{* * *} \\
(0.1015)\end{array}$ & $\begin{array}{c}-0.7863 * * * \\
(0.1360)\end{array}$ \\
\hline Suburb: large & $\begin{array}{c}-1.1949 * * * \\
(0.1215)\end{array}$ & $\begin{array}{c}-1.1984 * * * \\
(0.1250)\end{array}$ & $\begin{array}{c}-1.1460 * * * \\
(0.1611)\end{array}$ \\
\hline Suburb: midsize & $\begin{array}{c}-1.0877 * * * \\
(0.1796)\end{array}$ & $\begin{array}{c}-1.0098 * * * \\
(0.1776)\end{array}$ & $\begin{array}{c}-0.9019 * * * \\
(0.2284)\end{array}$ \\
\hline Town: fringe & $\begin{array}{c}-1.1447 * * * \\
(0.1866)\end{array}$ & $\begin{array}{c}-1.0625 * * * \\
(0.1845)\end{array}$ & $\begin{array}{c}-1.1477 * * * \\
(0.2449)\end{array}$ \\
\hline Town: distant & $\begin{array}{c}-0.6956 * * * \\
(0.0948)\end{array}$ & $\begin{array}{c}-0.6575 * * * \\
(0.0946)\end{array}$ & $\begin{array}{c}-0.6997 * * * \\
(0.1329)\end{array}$ \\
\hline Town: remote & $\begin{array}{c}-1.7687 * * * \\
(0.1573)\end{array}$ & $\begin{array}{c}-1.6826 * * * \\
(0.1554)\end{array}$ & $\begin{array}{c}-1.7315 * * * \\
(0.2111)\end{array}$ \\
\hline Rural: fringe & $\begin{array}{c}-1.0724 * * * \\
(0.1587)\end{array}$ & $\begin{array}{c}-1.0246 * * * \\
(0.1594)\end{array}$ & $\begin{array}{c}-0.9656 * * * \\
(0.2301)\end{array}$ \\
\hline Rural: distant & $\begin{array}{c}-1.6089 * * * \\
(0.3043)\end{array}$ & $\begin{array}{c}-1.5423 * * * \\
(0.3004)\end{array}$ & $\begin{array}{c}-1.7394 * * * \\
(0.4962)\end{array}$ \\
\hline Rural: remote & $-1.1323 * * *$ & $-1.1723 * * *$ & $-1.1042 * * *$ \\
\hline
\end{tabular}




\begin{tabular}{|c|c|c|c|}
\hline Regressors & $\begin{array}{c}\text { Graduate Rate } \\
\text { Sample }\end{array}$ & $\begin{array}{l}\text { Debt Load } \\
\text { Sample }\end{array}$ & $\begin{array}{c}\text { Median } \\
\text { Earnings } 10 \\
\text { Years Out } \\
\text { Sample }\end{array}$ \\
\hline & $(0.2575)$ & $(0.2521)$ & $(0.3279)$ \\
\hline Private, not for profit & $\begin{array}{c}-1.0293 * * * \\
(0.0873)\end{array}$ & $\begin{array}{c}-0.9593 * * * \\
(0.0863)\end{array}$ & $\begin{array}{c}-0.9662 * * * \\
(0.1194)\end{array}$ \\
\hline Constant & $\begin{array}{c}-1.8614 * * * \\
(0.2992)\end{array}$ & $\begin{array}{c}-1.9724 * * * \\
(0.2974)\end{array}$ & $\begin{array}{c}-2.0030 * * * \\
(0.4195)\end{array}$ \\
\hline Observations & 7,394 & 7,413 & 3,938 \\
\hline
\end{tabular}

Notes: Standard deviations in brackets. ${ }^{*},{ }^{\wedge},{ }^{+}=>$estimate statistically significantly different from zero at the $99 \%, 95 \%$, and $90 \%$ confidence level. Excluded size is under 1,000 students, excluded locale is large city, and excluded sector is public. No HBCUs have more than 20,000 students or are located in a small suburb. Year indicators are excluded from this first stage since their inclusions reduced the match statistics. 
Appendix C. Detailed Decompositions at Different Quantiles; Matched Sample Only.

Table C1 Decomposition of differences in 6-year Black graduation rates, comparing HBCU and non-HBCU graduates across quantiles, matched sample only.

\begin{tabular}{|c|c|c|c|c|}
\hline & $\begin{array}{c}\text { Mean } \\
\text { (from Table 2) }\end{array}$ & 25th Percentile & Median & 75th Percentile \\
\hline Median log annual earnings non-HBCU graduates & $\begin{array}{c}0.3263 * * * \\
(0.0096)\end{array}$ & $\begin{array}{c}0.1893 * * * \\
(0.0113)\end{array}$ & $\begin{array}{c}0.3048 * * * \\
(0.0110)\end{array}$ & $\begin{array}{c}0.4450 * * * \\
(0.0139)\end{array}$ \\
\hline Median log annual earnings HBCU graduates & $\begin{array}{c}0.3429 * * * \\
(0.0155)\end{array}$ & $\begin{array}{c}0.2563 * * * \\
(0.0188)\end{array}$ & $\begin{array}{c}0.3438 * * * \\
(0.0178)\end{array}$ & $\begin{array}{c}0.4199 * * * \\
(0.0162)\end{array}$ \\
\hline Observed median log earnings differential $\quad\left[\bar{Y}_{N}-\bar{Y}_{H}\right]=$ & $\begin{array}{l}-0.0166 \\
(0.0182)\end{array}$ & $\begin{array}{c}-0.0670 * * * \\
(0.0219)\end{array}$ & $\begin{array}{l}-0.0390 * \\
(0.0209)\end{array}$ & $\begin{array}{c}0.0251 \\
(0.0213)\end{array}$ \\
\hline \multicolumn{5}{|l|}{ Contribution of differences in: } \\
\hline Characteristics $\quad\left(\overline{\mathrm{M}}_{N}-\overline{\mathrm{M}}_{H}\right)^{\prime}\left\{\boldsymbol{\Psi} \widehat{\Lambda}_{N}+(\boldsymbol{I}-\boldsymbol{\Psi}) \widehat{\Lambda}_{H}\right\}=$ & $\begin{array}{c}0.0032 \\
(0.0269)\end{array}$ & $\begin{array}{c}-0.0816 \\
(0.0525)\end{array}$ & $\begin{array}{c}\mathbf{0 . 0 2 4 7} \\
(\mathbf{0 . 0 3 3 1 )}\end{array}$ & $\begin{array}{c}0.1145 * * * \\
(0.0319)\end{array}$ \\
\hline Institutional characteristics & $\begin{array}{c}0.0121 * * \\
(0.0056)\end{array}$ & $\begin{array}{c}0.0110 \\
(0.0085)\end{array}$ & $\begin{array}{l}0.0106^{*} \\
(0.0064)\end{array}$ & $\begin{array}{c}0.0116 \\
(0.0075)\end{array}$ \\
\hline Endowment-expense ratio & $\begin{array}{c}0.0004 \\
(0.0016)\end{array}$ & $\begin{array}{l}-0.0003 \\
(0.0011)\end{array}$ & $\begin{array}{l}-0.0000 \\
(0.0004)\end{array}$ & $\begin{array}{c}0.0003 \\
(0.0011)\end{array}$ \\
\hline Revenue per fte $-\$ 1000$ s & $\begin{array}{c}0.0008 \\
(0.0011)\end{array}$ & $\begin{array}{l}-0.0009 \\
(0.0013)\end{array}$ & $\begin{array}{l}-0.0006 \\
(0.0010)\end{array}$ & $\begin{array}{c}0.0005 \\
(0.0007)\end{array}$ \\
\hline In-state tuition and fees $-\$ 1000 \mathrm{~s}^{\mathrm{a}}$ & $\begin{array}{c}0.0107^{* *} \\
(0.0047)\end{array}$ & $\begin{array}{c}0.0117 * * \\
(0.0057)\end{array}$ & $\begin{array}{l}0.0111^{*} \\
(0.0061)\end{array}$ & $\begin{array}{c}0.0110 \\
(0.0067)\end{array}$ \\
\hline Student to Faculty ratio & $\begin{array}{c}0.0001 \\
(0.0006)\end{array}$ & $\begin{array}{c}0.0004 \\
(0.0017)\end{array}$ & $\begin{array}{c}0.0001 \\
(0.0004)\end{array}$ & $\begin{array}{l}-0.0002 \\
(0.0007)\end{array}$ \\
\hline Graduate program $=1$ & $\begin{array}{c}0.0000 \\
(0.0023)\end{array}$ & $\begin{array}{c}0.0001 \\
(0.0061)\end{array}$ & $\begin{array}{c}0.0001 \\
(0.0031)\end{array}$ & $\begin{array}{l}-0.0000 \\
(0.0014)\end{array}$ \\
\hline Student body characteristics & $\begin{array}{l}-0.0093 \\
(0.0251)\end{array}$ & $\begin{array}{l}-0.0928^{*} \\
(0.0507)\end{array}$ & $\begin{array}{c}0.0135 \\
(0.0317)\end{array}$ & $\begin{array}{c}0.1026 * * * \\
(0.0302)\end{array}$ \\
\hline Share of 1 st gen. college students & $\begin{array}{c}0.0006 \\
(0.0067)\end{array}$ & $\begin{array}{c}0.0006 \\
(0.0073)\end{array}$ & $\begin{array}{c}0.0007 \\
(0.0077)\end{array}$ & $\begin{array}{c}0.0007 \\
(0.0084)\end{array}$ \\
\hline Share of undergrads who receive a Pell grant ${ }^{\mathrm{a}}$ & $\begin{array}{c}0.0153 \\
(0.0135)\end{array}$ & $\begin{array}{c}0.0030 \\
(0.0193)\end{array}$ & $\begin{array}{c}0.0160 \\
(0.0176)\end{array}$ & $\begin{array}{c}0.0014 \\
(0.0191)\end{array}$ \\
\hline Average SAT equivalent score of students admitted ${ }^{\mathrm{a}}$ & $\begin{array}{c}0.0469 * * * \\
(0.0131)\end{array}$ & $\begin{array}{l}0.0333^{*} \\
(0.0173)\end{array}$ & $\begin{array}{c}0.0431 * * * \\
(0.0156)\end{array}$ & $\begin{array}{c}0.0536 * * * \\
(0.0186)\end{array}$ \\
\hline
\end{tabular}

C -1 


\begin{tabular}{|c|c|c|c|c|}
\hline & $\begin{array}{c}\text { Mean } \\
\text { (from Table 2) }\end{array}$ & 25th Percentile & Median & 75th Percentile \\
\hline \multirow[t]{2}{*}{ Share of female students } & -0.0013 & -0.0019 & -0.0012 & -0.0008 \\
\hline & $(0.0031)$ & $(0.0043)$ & $(0.0028)$ & $(0.0019)$ \\
\hline \multirow{2}{*}{ Share of Non-Hispanic Black Students ${ }^{a}$} & -0.0448 & $-0.0958 *$ & -0.0215 & $0.0764 * *$ \\
\hline & $(0.0279)$ & $(0.0553)$ & $(0.0350)$ & $(0.0347)$ \\
\hline \multirow[t]{2}{*}{ Share of STEM graduates } & -0.0007 & -0.0001 & -0.0002 & -0.0009 \\
\hline & $(0.0012)$ & $(0.0009)$ & $(0.0008)$ & $(0.0016)$ \\
\hline \multirow[t]{2}{*}{ Share of part-time students ${ }^{\mathrm{a}}$} & $-0.0253 * * *$ & $-0.0319 * * *$ & $-0.0233 * * *$ & $-0.0278 * *$ \\
\hline & $(0.0080)$ & $(0.0096)$ & $(0.0090)$ & $(0.0111)$ \\
\hline \multirow{2}{*}{ Year fixed effects } & 0.0004 & 0.0001 & 0.0006 & 0.0002 \\
\hline & $(0.0004)$ & $(0.0006)$ & $(0.0006)$ & $(0.0005)$ \\
\hline \multirow[t]{2}{*}{ Coefficients $\quad\left\{(\boldsymbol{I}-\boldsymbol{\Psi})^{\prime} \overline{\mathrm{M}}_{N}+\boldsymbol{\Psi}^{\prime} \overline{\mathrm{M}}_{H}\right\}\left(\widehat{\Lambda}_{N}-\widehat{\Lambda}_{H}\right)=$} & -0.0198 & 0.0146 & $-0.0637 *$ & $-0.0894 * * *$ \\
\hline & $(0.0249)$ & $(0.0572)$ & $(0.0341)$ & $(\mathbf{0 . 0 3 0 4 )}$ \\
\hline \multirow{2}{*}{ Institutional characteristics } & 0.0607 & 0.0607 & 0.0824 & 0.1223 \\
\hline & $(0.0714)$ & $(0.0714)$ & $(0.1187)$ & $(0.0833)$ \\
\hline \multirow[t]{2}{*}{ Endowment-expense ratio } & -0.0166 & 0.0073 & 0.0081 & -0.0041 \\
\hline & $(0.0106)$ & $(0.0136)$ & $(0.0150)$ & $(0.0167)$ \\
\hline \multirow[t]{2}{*}{ Revenue per fte - $\$ 1000$ s } & 0.0067 & 0.0459 & 0.0255 & -0.0194 \\
\hline & $(0.0229)$ & $(0.0335)$ & $(0.0285)$ & $(0.0211)$ \\
\hline \multirow[t]{2}{*}{ In-state tuition and fees $-\$ 1000 \mathrm{~s}^{\mathrm{a}}$} & 0.0365 & 0.0363 & 0.0249 & 0.0132 \\
\hline & $(0.0262)$ & $(0.0362)$ & $(0.0447)$ & $(0.0390)$ \\
\hline \multirow[t]{2}{*}{ Student to Faculty ratio } & 0.0159 & -0.0327 & 0.0532 & 0.0652 \\
\hline & $(0.0540)$ & $(0.0945)$ & $(0.0671)$ & $(0.0687)$ \\
\hline \multirow[t]{2}{*}{ Graduate program $=1$} & 0.0182 & 0.0257 & 0.0107 & -0.0022 \\
\hline & $(0.0156)$ & $(0.0218)$ & $(0.0217)$ & $(0.0222)$ \\
\hline \multirow[t]{2}{*}{ Student body characteristics } & $0.4824 * *$ & $0.4824 * *$ & $0.5767 *$ & 0.4165 \\
\hline & $(0.2308)$ & $(0.2308)$ & $(0.3010)$ & $(0.2771)$ \\
\hline \multirow[t]{2}{*}{ Share of 1 st gen. college students } & $0.2344 * *$ & $0.3696 * * *$ & $0.2049 * *$ & 0.0905 \\
\hline & $(0.0969)$ & $(0.1228)$ & $(0.1044)$ & $(0.1254)$ \\
\hline \multirow[t]{2}{*}{ Share of undergrads who receive a Pell grant ${ }^{\mathrm{a}}$} & 0.0551 & 0.0063 & 0.0497 & 0.0386 \\
\hline & $(0.0538)$ & $(0.0732)$ & $(0.0660)$ & $(0.0802)$ \\
\hline \multirow[t]{2}{*}{ Average SAT equivalent score of students admitted ${ }^{\mathrm{a}}$} & 0.2068 & 0.2116 & 0.0798 & $0.3744^{*}$ \\
\hline & $(0.1497)$ & $(0.2058)$ & $(0.1892)$ & $(0.2253)$ \\
\hline
\end{tabular}

C - 2 


\begin{tabular}{|c|c|c|c|c|}
\hline & $\begin{array}{c}\text { Mean } \\
\text { (from Table 2) }\end{array}$ & 25th Percentile & Median & 75th Percentile \\
\hline Share of female students & $\begin{array}{c}0.0030 \\
(0.0553)\end{array}$ & $\begin{array}{c}0.0248 \\
(0.0675)\end{array}$ & $\begin{array}{l}-0.0182 \\
(0.0693)\end{array}$ & $\begin{array}{c}0.0357 \\
(0.0983)\end{array}$ \\
\hline Share of Non-Hispanic Black Students ${ }^{\mathrm{a}}$ & $\begin{array}{l}-0.0142 \\
(0.0359)\end{array}$ & $\begin{array}{l}-0.0034 \\
(0.0755)\end{array}$ & $\begin{array}{c}0.0331 \\
(0.0490)\end{array}$ & $\begin{array}{l}-0.0349 \\
(0.0433)\end{array}$ \\
\hline Share of STEM graduates & $\begin{array}{c}0.0127 \\
(0.0186)\end{array}$ & $\begin{array}{l}-0.0080 \\
(0.0252)\end{array}$ & $\begin{array}{c}0.0317 \\
(0.0237)\end{array}$ & $\begin{array}{l}-0.0160 \\
(0.0257)\end{array}$ \\
\hline Share of part-time students ${ }^{\mathrm{a}}$ & $\begin{array}{l}-0.0153 \\
(0.0212)\end{array}$ & $\begin{array}{l}-0.0242 \\
(0.0280)\end{array}$ & $\begin{array}{c}0.0354 \\
(0.0305)\end{array}$ & $\begin{array}{c}0.0001 \\
(0.0279)\end{array}$ \\
\hline Year & $\begin{array}{l}-0.0128 \\
(0.0197)\end{array}$ & $\begin{array}{c}0.0077 \\
(0.0292)\end{array}$ & $\begin{array}{l}-0.0420 * \\
(0.0240)\end{array}$ & $\begin{array}{l}-0.0143 \\
(0.0304)\end{array}$ \\
\hline Constant & $\begin{array}{c}-0.5502 * * \\
(0.2490)\end{array}$ & $\begin{array}{c}-0.6522 * * \\
(0.3225)\end{array}$ & $\begin{array}{l}-0.5606 * \\
(0.3062)\end{array}$ & $\begin{array}{l}-0.6162 \\
(0.3854)\end{array}$ \\
\hline Combined total institution years & 2,929 & 2,929 & 2,929 & 2,929 \\
\hline
\end{tabular}

Notes: Standard errors in parentheses. ${ }^{* * *} \mathrm{p}<0.01,{ }^{*} \mathrm{p}<0.05, * \mathrm{p}<0.1$. Matched sample created using between 1 and 20 nearest-neighbor matches with replacement. Regression parameter estimates are available upon request; errors are clustered at the institution ID level in those regressions. Years of analysis are 2009 through 2018.

${ }^{a}$ Regressors not included in the first-stage probit estimated for construction of p-score. 
Table C2 Decomposition of log median debt load (\$2016, thousands), comparing HBCU and non-HBCU graduates across quantiles, matched sample only.

\begin{tabular}{|c|c|c|c|c|}
\hline & $\begin{array}{c}\text { Mean } \\
\text { (from Table 2) }\end{array}$ & 25th Percentile & Median & 75th Percentile \\
\hline Median log annual earnings non-HBCU graduates & $\begin{array}{l}9.8865 * * * \\
(0.0164)\end{array}$ & $\begin{array}{l}9.7514 * * * \\
(0.0224)\end{array}$ & $\begin{array}{l}9.9145^{* * *} \\
(0.0178)\end{array}$ & $\begin{array}{c}10.0946^{* * *} \\
(0.0142)\end{array}$ \\
\hline Median log annual earnings HBCU graduates & $\begin{array}{c}10.1808 * * * \\
(0.0240)\end{array}$ & $\begin{array}{c}10.0587 * * * \\
(0.0335)\end{array}$ & $\begin{array}{c}10.2198 * * * \\
(0.0213)\end{array}$ & $\begin{array}{c}10.3483 * * * \\
(0.0221)\end{array}$ \\
\hline Observed median log earnings differential $\quad\left[\bar{Y}_{N}-\bar{Y}_{H}\right]=$ & $\begin{array}{c}-0.2942 * * * \\
(0.0291)\end{array}$ & $\begin{array}{c}-0.3073 * * * \\
(0.0403)\end{array}$ & $\begin{array}{c}-0.3053 * * * \\
(0.0278)\end{array}$ & $\begin{array}{c}-0.2537 * * * \\
(0.0263)\end{array}$ \\
\hline \multicolumn{5}{|l|}{ Contribution of differences in: } \\
\hline Characteristics $\quad\left(\overline{\mathrm{M}}_{N}-\overline{\mathrm{M}}_{H}\right)^{\prime}\left\{\boldsymbol{\Psi} \widehat{\Lambda}_{N}+(\boldsymbol{I}-\boldsymbol{\Psi}) \widehat{\Lambda}_{H}\right\}=$ & $\begin{array}{c}-0.1506 * * \\
(0.0738)\end{array}$ & $\begin{array}{c}-0.3132 * * * \\
(0.0930)\end{array}$ & $\begin{array}{c}-0.1418 * * * \\
(0.0479)\end{array}$ & $\begin{array}{c}-0.1543 * * * \\
(0.0473)\end{array}$ \\
\hline Institutional characteristics & $\begin{array}{l}0.0461 * * * \\
(0.0131)\end{array}$ & $\begin{array}{l}0.0510^{* * *} \\
(0.0163)\end{array}$ & $\begin{array}{c}0.0546^{* * *} \\
(0.0132)\end{array}$ & $\begin{array}{l}0.0583 * * * \\
(0.0129)\end{array}$ \\
\hline Endowment-expense ratio & $\begin{array}{l}-0.0009 \\
(0.0040)\end{array}$ & $\begin{array}{l}-0.0015 \\
(0.0072)\end{array}$ & $\begin{array}{l}-0.0010 \\
(0.0046)\end{array}$ & $\begin{array}{l}-0.0007 \\
(0.0031)\end{array}$ \\
\hline Revenue per fte $-\$ 1000$ s & $\begin{array}{l}-0.0082 \\
(0.0089)\end{array}$ & $\begin{array}{l}-0.0105 \\
(0.0112)\end{array}$ & $\begin{array}{l}-0.0057 \\
(0.0061)\end{array}$ & $\begin{array}{l}-0.0032 \\
(0.0034)\end{array}$ \\
\hline In-state tuition and fees $-\$ 1000 \mathrm{~s}^{\mathrm{a}}$ & $\begin{array}{c}0.0554 * * * \\
(0.0134)\end{array}$ & $\begin{array}{c}0.0632 * * * \\
(0.0158)\end{array}$ & $\begin{array}{c}0.0616^{* * *} \\
(0.0150)\end{array}$ & $\begin{array}{c}0.0623 * * * \\
(0.0147)\end{array}$ \\
\hline Student to Faculty ratio & $\begin{array}{l}-0.0002 \\
(0.0019)\end{array}$ & $\begin{array}{l}-0.0003 \\
(0.0033)\end{array}$ & $\begin{array}{c}-0.0002 \\
(0.0017)\end{array}$ & $\begin{array}{l}-0.0001 \\
(0.0010)\end{array}$ \\
\hline Graduate program $=1$ & $\begin{array}{l}-0.0000 \\
(0.0003)\end{array}$ & $\begin{array}{c}0.0001 \\
(0.0010)\end{array}$ & $\begin{array}{l}-0.0001 \\
(0.0011)\end{array}$ & $\begin{array}{l}-0.0001 \\
(0.0006)\end{array}$ \\
\hline Student body characteristics & $\begin{array}{c}-0.1951 * * * \\
(0.0725)\end{array}$ & $\begin{array}{c}-0.3616^{* * *} \\
(0.0921)\end{array}$ & $\begin{array}{c}-0.1951 * * * \\
(0.0458)\end{array}$ & $\begin{array}{c}-0.2111 * * * \\
(0.0451)\end{array}$ \\
\hline Share of 1st gen. college students & $\begin{array}{c}0.0022 \\
(0.0078)\end{array}$ & $\begin{array}{c}0.0031 \\
(0.0110)\end{array}$ & $\begin{array}{c}0.0015 \\
(0.0053)\end{array}$ & $\begin{array}{c}0.0006 \\
(0.0022)\end{array}$ \\
\hline Share of undergrads who receive a Pell grant ${ }^{\mathrm{a}}$ & $\begin{array}{l}-0.0756^{*} \\
(0.0453)\end{array}$ & $\begin{array}{l}-0.0477 \\
(0.0411)\end{array}$ & $\begin{array}{c}-0.0637 * * \\
(0.0309)\end{array}$ & $\begin{array}{c}-0.0677 * * \\
(0.0265)\end{array}$ \\
\hline Average SAT equivalent score of students admitted ${ }^{\mathrm{a}}$ & $\begin{array}{l}-0.0354 \\
(0.0259)\end{array}$ & $\begin{array}{l}-0.0244 \\
(0.0331)\end{array}$ & $\begin{array}{c}-0.0554 * * \\
(0.0273)\end{array}$ & $\begin{array}{c}-0.0794 * * * \\
(0.0233)\end{array}$ \\
\hline Share of female students & -0.0001 & -0.0001 & -0.0007 & -0.0007 \\
\hline
\end{tabular}




\begin{tabular}{|c|c|c|c|c|}
\hline & $\begin{array}{c}\text { Mean } \\
\text { (from Table 2) }\end{array}$ & 25th Percentile & Median & 75th Percentile \\
\hline \multirow{3}{*}{ Share of Non-Hispanic Black Students ${ }^{\mathrm{a}}$} & $(0.0015)$ & $(0.0020)$ & $(0.0022)$ & $(0.0020)$ \\
\hline & -0.0660 & $-0.2827 * * *$ & -0.0576 & -0.0334 \\
\hline & $(0.0836)$ & $(0.1006)$ & $(0.0565)$ & $(0.0484)$ \\
\hline \multirow[t]{2}{*}{ Share of STEM graduates } & 0.0003 & 0.0001 & 0.0002 & 0.0020 \\
\hline & $(0.0016)$ & $(0.0021)$ & $(0.0018)$ & $(0.0029)$ \\
\hline \multirow[t]{2}{*}{ Share of part-time students ${ }^{\mathrm{a}}$} & -0.0206 & -0.0099 & -0.0192 & $-0.0324 * * *$ \\
\hline & $(0.0133)$ & $(0.0190)$ & $(0.0165)$ & $(0.0125)$ \\
\hline \multirow[t]{2}{*}{ Year fixed effects } & -0.0016 & -0.0026 & -0.0013 & -0.0015 \\
\hline & $(0.0027)$ & $(0.0036)$ & $(0.0033)$ & $(0.0026)$ \\
\hline \multirow{2}{*}{ Coefficients $\quad\left\{(\boldsymbol{I}-\boldsymbol{\Psi})^{\prime} \overline{\mathrm{M}}_{N}+\boldsymbol{\Psi}^{\prime} \overline{\mathrm{M}}_{H}\right\}\left(\widehat{\Lambda}_{N}-\widehat{\Lambda}_{H}\right)=$} & $-0.1436 *$ & 0.0059 & $-0.1636 * * *$ & $-0.0994 * *$ \\
\hline & $(0.0800)$ & $(0.0980)$ & $(0.0504)$ & $(0.0439)$ \\
\hline \multirow[t]{2}{*}{ Institutional characteristics } & $-0.2548 *$ & $-0.4508 * *$ & -0.0970 & -0.1875 \\
\hline & $(0.1406)$ & $(0.2085)$ & $(0.1418)$ & $(0.1417)$ \\
\hline \multirow{2}{*}{ Endowment-expense ratio } & $0.0330 *$ & $0.0468 * *$ & 0.0212 & 0.0064 \\
\hline & $(0.0182)$ & $(0.0232)$ & $(0.0161)$ & $(0.0192)$ \\
\hline \multirow[t]{2}{*}{ Revenue per fte - $\$ 1000$ s } & -0.0079 & $-0.1089 *$ & 0.0609 & 0.0007 \\
\hline & $(0.0520)$ & $(0.0609)$ & $(0.0413)$ & $(0.0395)$ \\
\hline \multirow[t]{2}{*}{ In-state tuition and fees $-\$ 1000 \mathrm{~s}^{\mathrm{a}}$} & 0.0040 & -0.0710 & 0.0107 & -0.0091 \\
\hline & $(0.0500)$ & $(0.0661)$ & $(0.0542)$ & $(0.0510)$ \\
\hline \multirow[t]{2}{*}{ Student to Faculty ratio } & $-0.2947 * *$ & $-0.2893 *$ & -0.1534 & -0.1709 \\
\hline & $(0.1244)$ & $(0.1758)$ & $(0.1195)$ & $(0.1119)$ \\
\hline \multirow[t]{2}{*}{ Graduate program $=1$} & 0.0108 & -0.0284 & -0.0364 & -0.0146 \\
\hline & $(0.0286)$ & $(0.0377)$ & $(0.0314)$ & $(0.0248)$ \\
\hline \multirow[t]{2}{*}{ Student body characteristics } & -0.1825 & -0.2979 & -0.4333 & -0.4474 \\
\hline & $(0.3932)$ & $(0.5845)$ & $(0.4396)$ & $(0.3903)$ \\
\hline \multirow[t]{2}{*}{ Share of 1 st gen. college students } & 0.1154 & -0.0045 & $-0.2459 *$ & $-0.2256^{*}$ \\
\hline & $(0.1957)$ & $(0.1874)$ & $(0.1418)$ & $(0.1320)$ \\
\hline \multirow[t]{2}{*}{ Share of undergrads who receive a Pell grant ${ }^{\mathrm{a}}$} & $-0.2964 * * *$ & $-0.4292 * * *$ & $-0.2229 * *$ & $-0.2562 * * *$ \\
\hline & $(0.1132)$ & $(0.1348)$ & $(0.1102)$ & $(0.0911)$ \\
\hline \multirow[t]{2}{*}{ Average SAT equivalent score of students admitted ${ }^{\mathrm{a}}$} & -0.2634 & 0.0194 & -0.1148 & -0.2245 \\
\hline & $(0.2845)$ & $(0.3983)$ & $(0.2940)$ & $(0.2599)$ \\
\hline Share of female students & 0.0603 & -0.0346 & 0.0095 & 0.1265 \\
\hline
\end{tabular}




\begin{tabular}{|c|c|c|c|c|}
\hline & $\begin{array}{c}\text { Mean } \\
\text { (from Table 2) }\end{array}$ & 25th Percentile & Median & 75th Percentile \\
\hline \multirow{3}{*}{ Share of Non-Hispanic Black Students } & $(0.1314)$ & $(0.1518)$ & $(0.1169)$ & $(0.1123)$ \\
\hline & -0.0253 & -0.0647 & -0.0232 & 0.0211 \\
\hline & $(0.1185)$ & $(0.1211)$ & $(0.0780)$ & $(0.0654)$ \\
\hline \multirow[t]{2}{*}{ Share of STEM graduates } & $0.1276^{* * *}$ & 0.0906 & $0.0847 * *$ & $0.0863 * *$ \\
\hline & $(0.0413)$ & $(0.0585)$ & $(0.0394)$ & $(0.0376)$ \\
\hline \multirow[t]{2}{*}{ Share of part-time students ${ }^{\mathrm{a}}$} & $0.0993^{*}$ & $0.1250 * *$ & $0.0793 *$ & 0.0249 \\
\hline & $(0.0507)$ & $(0.0618)$ & $(0.0421)$ & $(0.0366)$ \\
\hline \multirow[t]{2}{*}{ Year } & -0.0311 & $-0.1214 * *$ & 0.0431 & $0.0641 * *$ \\
\hline & $(0.0296)$ & $(0.0579)$ & $(0.0386)$ & $(0.0324)$ \\
\hline \multirow[t]{2}{*}{ Constant } & 0.3248 & 0.8760 & 0.3236 & 0.4714 \\
\hline & $(0.3983)$ & $(0.6064)$ & $(0.4545)$ & $(0.4067)$ \\
\hline Combined total institution years & 3,035 & 3,035 & 3,035 & 3,035 \\
\hline
\end{tabular}


Table C3 Decomposition of llog median annual earnings (\$2016, thousands) 10 years after matriculation, comparing HBCU and nonHBCU graduates across quantiles, matched sample only.

\begin{tabular}{|c|c|c|c|c|}
\hline & $\begin{array}{c}\text { Mean } \\
\text { (from Table 2) }\end{array}$ & 25th Percentile & Median & 75th Percentile \\
\hline Median log annual earnings non-HBCU graduates & $\begin{array}{c}10.6585 * * * \\
(0.0168)\end{array}$ & $\begin{array}{c}10.5127 * * * \\
(0.0157)\end{array}$ & $\begin{array}{c}10.6309 * * * \\
(0.0155)\end{array}$ & $\begin{array}{c}10.7615 * * * \\
(0.0198)\end{array}$ \\
\hline Median log annual earnings HBCU graduates & $\begin{array}{c}10.3900 * * * \\
(0.0202)\end{array}$ & $\begin{array}{c}10.2721 * * * \\
(0.0211)\end{array}$ & $\begin{array}{c}10.3747 * * * \\
(0.0232)\end{array}$ & $\begin{array}{c}10.4790 * * * \\
(0.0222)\end{array}$ \\
\hline Observed median log earnings differential $\quad\left[\bar{Y}_{N}-\bar{Y}_{H}\right]=$ & $\begin{array}{c}0.2685 * * * \\
(0.0262)\end{array}$ & $\begin{array}{c}0.2406 * * * \\
(0.0263)\end{array}$ & $\begin{array}{c}0.2563 * * * \\
(0.0279)\end{array}$ & $\begin{array}{c}0.2825 * * * \\
(0.0297)\end{array}$ \\
\hline \multicolumn{5}{|l|}{ Contribution of differences in: } \\
\hline Characteristics $\quad\left(\overline{\mathrm{M}}_{N}-\overline{\mathrm{M}}_{H}\right)^{\prime}\left\{\boldsymbol{\Psi} \widehat{\Lambda}_{N}+(\boldsymbol{I}-\boldsymbol{\Psi}) \widehat{\Lambda}_{H}\right\}=$ & $\begin{array}{c}0.1758 * * * \\
(\mathbf{0 . 0 3 5 8 )}\end{array}$ & $\begin{array}{c}0.2537 * * * \\
(0.0448)\end{array}$ & $\begin{array}{c}0.1651 * * * \\
(0.0523)\end{array}$ & $\begin{array}{c}0.1581 * * * \\
(0.0464)\end{array}$ \\
\hline Institutional characteristics & $\begin{array}{c}0.0284 * * \\
(0.0113)\end{array}$ & $\begin{array}{c}0.0345 * * * \\
(0.0132)\end{array}$ & $\begin{array}{c}0.0306 * * * \\
(0.0109)\end{array}$ & $\begin{array}{c}0.0337 * * \\
(0.0131)\end{array}$ \\
\hline Endowment-expense ratio & $\begin{array}{l}-0.0000 \\
(0.0009)\end{array}$ & $\begin{array}{c}0.0001 \\
(0.0026)\end{array}$ & $\begin{array}{c}0.0000 \\
(0.0008)\end{array}$ & $\begin{array}{l}-0.0000 \\
(0.0005)\end{array}$ \\
\hline Revenue per fte - \$1000s & $\begin{array}{c}0.0002 \\
(0.0009)\end{array}$ & $\begin{array}{l}-0.0019 \\
(0.0025)\end{array}$ & $\begin{array}{l}-0.0013 \\
(0.0018)\end{array}$ & $\begin{array}{l}-0.0005 \\
(0.0013)\end{array}$ \\
\hline In-state tuition and fees $-\$ 1000 \mathrm{~s}^{\mathrm{a}}$ & $\begin{array}{c}0.0283 * * * \\
(0.0099)\end{array}$ & $\begin{array}{c}0.0368 * * * \\
(0.0102)\end{array}$ & $\begin{array}{c}0.0319 * * * \\
(0.0094)\end{array}$ & $\begin{array}{c}0.0339 * * * \\
(0.0121)\end{array}$ \\
\hline Student to Faculty ratio & $\begin{array}{l}-0.0001 \\
(0.0004)\end{array}$ & $\begin{array}{l}-0.0005 \\
(0.0030)\end{array}$ & $\begin{array}{l}-0.0001 \\
(0.0005)\end{array}$ & $\begin{array}{c}0.0003 \\
(0.0020)\end{array}$ \\
\hline Graduate program $=1$ & $\begin{array}{c}0.0000 \\
(0.0062)\end{array}$ & $\begin{array}{c}0.0000 \\
(0.0100)\end{array}$ & $\begin{array}{c}0.0000 \\
(0.0076)\end{array}$ & $\begin{array}{c}0.0000 \\
(0.0050)\end{array}$ \\
\hline Student body characteristics & $\begin{array}{c}0.1487 * * * \\
(0.0330)\end{array}$ & $\begin{array}{c}0.2205 * * * \\
(0.0432)\end{array}$ & $\begin{array}{c}0.1359 * * * \\
(0.0509)\end{array}$ & $\begin{array}{c}0.1261 * * * \\
(0.0427)\end{array}$ \\
\hline Share of 1st gen. college students & $\begin{array}{l}-0.0001 \\
(0.0007)\end{array}$ & $\begin{array}{c}0.0004 \\
(0.0016)\end{array}$ & $\begin{array}{l}-0.0002 \\
(0.0009)\end{array}$ & $\begin{array}{l}-0.0005 \\
(0.0022)\end{array}$ \\
\hline Share of undergrads who receive a Pell grant ${ }^{\mathrm{a}}$ & $\begin{array}{c}0.1486 * * * \\
(0.0253)\end{array}$ & $\begin{array}{c}0.1247 * * * \\
(0.0339)\end{array}$ & $\begin{array}{c}0.1692 * * * \\
(0.0319)\end{array}$ & $\begin{array}{c}0.1509 * * * \\
(0.0347)\end{array}$ \\
\hline Average SAT equivalent score of students admitted ${ }^{\mathrm{a}}$ & $\begin{array}{c}0.0704 * * * \\
(0.0228)\end{array}$ & $\begin{array}{c}0.0316 \\
(0.0252)\end{array}$ & $\begin{array}{l}0.0429 * \\
(0.0253)\end{array}$ & $\begin{array}{c}0.0662 * * \\
(0.0320)\end{array}$ \\
\hline Share of female students & $\begin{array}{c}0.0009 \\
(0.0028)\end{array}$ & $\begin{array}{l}-0.0005 \\
(0.0016)\end{array}$ & $\begin{array}{c}0.0001 \\
(0.0006)\end{array}$ & $\begin{array}{c}0.0010 \\
(0.0031)\end{array}$ \\
\hline
\end{tabular}

C -1 


\begin{tabular}{|c|c|c|c|c|}
\hline & $\begin{array}{c}\text { Mean } \\
\text { (from Table 2) }\end{array}$ & 25th Percentile & Median & 75th Percentile \\
\hline Share of Non-Hispanic Black Students ${ }^{\mathrm{a}}$ & $\begin{array}{c}-0.0685 \\
(0.0433)\end{array}$ & $\begin{array}{c}0.0619 \\
(0.0503)\end{array}$ & $\begin{array}{c}-0.0834 \\
(0.0584)\end{array}$ & $\begin{array}{c}-0.1117^{*} \\
(0.0587)\end{array}$ \\
\hline Share of STEM graduates & $\begin{array}{c}0.0008 \\
(0.0037)\end{array}$ & $\begin{array}{c}0.0005 \\
(0.0023)\end{array}$ & $\begin{array}{c}0.0007 \\
(0.0034)\end{array}$ & $\begin{array}{c}0.0012 \\
(0.0054)\end{array}$ \\
\hline Share of part-time students ${ }^{\mathrm{a}}$ & $\begin{array}{l}-0.0034 \\
(0.0114)\end{array}$ & $\begin{array}{c}0.0018 \\
(0.0127)\end{array}$ & $\begin{array}{c}0.0065 \\
(0.0150)\end{array}$ & $\begin{array}{c}0.0190 \\
(0.0181)\end{array}$ \\
\hline Year fixed effects & $\begin{array}{l}-0.0014 \\
(0.0011)\end{array}$ & $\begin{array}{l}-0.0013 \\
(0.0014)\end{array}$ & $\begin{array}{l}-0.0014 \\
(0.0012)\end{array}$ & $\begin{array}{l}-0.0017 \\
(0.0016)\end{array}$ \\
\hline Coefficients $\quad\left\{(\boldsymbol{I}-\boldsymbol{\Psi})^{\prime} \overline{\mathrm{M}}_{N}+\boldsymbol{\Psi}^{\prime} \overline{\mathrm{M}}_{H}\right\}\left(\widehat{\Lambda}_{N}-\widehat{\Lambda}_{H}\right)=$ & $\begin{array}{c}0.0927 * * * \\
(0.0345)\end{array}$ & $\begin{array}{l}-0.0131 \\
(0.0424)\end{array}$ & $\begin{array}{l}0.0911 * \\
(0.0532)\end{array}$ & $\begin{array}{c}0.1244 * * * \\
(0.0456)\end{array}$ \\
\hline Institutional characteristics & $\begin{array}{l}-0.0257 \\
(0.1070)\end{array}$ & $\begin{array}{l}-0.0303 \\
(0.1322)\end{array}$ & $\begin{array}{l}-0.0688 \\
(0.1595)\end{array}$ & $\begin{array}{c}0.0086 \\
(0.1637)\end{array}$ \\
\hline Endowment-expense ratio & $\begin{array}{l}-0.0393 * * * \\
\quad(0.0121)\end{array}$ & $\begin{array}{l}-0.0364 * \\
(0.0187)\end{array}$ & $\begin{array}{l}-0.0277 \\
(0.0184)\end{array}$ & $\begin{array}{l}-0.0572 * * * \\
(0.0157)\end{array}$ \\
\hline Revenue per fte - $\$ 1000$ s & $\begin{array}{l}-0.0254 \\
(0.0262)\end{array}$ & $\begin{array}{l}-0.0391 \\
(0.0465)\end{array}$ & $\begin{array}{l}-0.0575 \\
(0.0568)\end{array}$ & $\begin{array}{l}-0.0466 \\
(0.0362)\end{array}$ \\
\hline In-state tuition and fees $-\$ 1000 \mathrm{~s}^{\mathrm{a}}$ & $\begin{array}{l}0.0638 * \\
(0.0332)\end{array}$ & $\begin{array}{c}0.1041 * * \\
(0.0511)\end{array}$ & $\begin{array}{c}0.0668 \\
(0.0534)\end{array}$ & $\begin{array}{c}0.1046 * * \\
(0.0509)\end{array}$ \\
\hline Student to Faculty ratio & $\begin{array}{c}0.0187 \\
(0.0942)\end{array}$ & $\begin{array}{l}-0.0691 \\
(0.1033)\end{array}$ & $\begin{array}{c}-0.0286 \\
(0.1307)\end{array}$ & $\begin{array}{c}0.0812 \\
(0.1334)\end{array}$ \\
\hline Graduate program $=1$ & $\begin{array}{c}-0.0436 * * \\
(0.0213)\end{array}$ & $\begin{array}{c}0.0104 \\
(0.0250)\end{array}$ & $\begin{array}{l}-0.0218 \\
(0.0303)\end{array}$ & $\begin{array}{c}-0.0733 * * * \\
(0.0282)\end{array}$ \\
\hline Student body characteristics & $\begin{array}{l}-0.1975 \\
(0.3939)\end{array}$ & $\begin{array}{c}0.6666 \\
(0.4543)\end{array}$ & $\begin{array}{c}0.6619 \\
(0.4707)\end{array}$ & $\begin{array}{l}-0.3821 \\
(0.5468)\end{array}$ \\
\hline Share of 1st gen. college students & $\begin{array}{c}0.1026 \\
(0.1112)\end{array}$ & $\begin{array}{c}0.3693 * * * \\
(0.1409)\end{array}$ & $\begin{array}{c}0.1358 \\
(0.1598)\end{array}$ & $\begin{array}{l}-0.1546 \\
(0.1711)\end{array}$ \\
\hline Share of undergrads who receive a Pell grant ${ }^{\mathrm{a}}$ & $\begin{array}{c}0.0049 \\
(0.0987)\end{array}$ & $\begin{array}{c}-0.1360 \\
(0.1336)\end{array}$ & $\begin{array}{l}0.2094 * \\
(0.1261)\end{array}$ & $\begin{array}{c}0.0730 \\
(0.1349)\end{array}$ \\
\hline Average SAT equivalent score of students admitted ${ }^{\mathrm{a}}$ & $\begin{array}{l}-0.2172 \\
(0.2515)\end{array}$ & $\begin{array}{c}0.2156 \\
(0.3132)\end{array}$ & $\begin{array}{c}0.3970 \\
(0.3101)\end{array}$ & $\begin{array}{l}-0.4359 \\
(0.3915)\end{array}$ \\
\hline Share of female students & $\begin{array}{c}-0.2285^{* *} \\
(0.1127)\end{array}$ & $\begin{array}{l}-0.0534 \\
(0.0979)\end{array}$ & $\begin{array}{c}-0.1893 * \\
(0.1071)\end{array}$ & $\begin{array}{c}0.0301 \\
(0.1159)\end{array}$ \\
\hline
\end{tabular}

C - 2 


\begin{tabular}{|c|c|c|c|c|}
\hline & $\begin{array}{c}\text { Mean } \\
\text { (from Table 2) }\end{array}$ & 25th Percentile & Median & 75th Percentile \\
\hline Share of Non-Hispanic Black Students ${ }^{\mathrm{a}}$ & $\begin{array}{c}0.0511 \\
(0.0678)\end{array}$ & $\begin{array}{c}0.1805 * * \\
(0.0815)\end{array}$ & $\begin{array}{l}-0.0022 \\
(0.0868)\end{array}$ & $\begin{array}{l}-0.0266 \\
(0.0866)\end{array}$ \\
\hline Share of STEM graduates & $\begin{array}{c}0.0650 * * * \\
(0.0251)\end{array}$ & $\begin{array}{c}0.0969 * * * \\
(0.0317)\end{array}$ & $\begin{array}{c}0.0412 \\
(0.0349)\end{array}$ & $\begin{array}{c}0.0673 * * \\
(0.0319)\end{array}$ \\
\hline Share of part-time students ${ }^{\mathrm{a}}$ & $\begin{array}{c}0.0247 \\
(0.0269)\end{array}$ & $\begin{array}{l}-0.0062 \\
(0.0313)\end{array}$ & $\begin{array}{l}0.0699 * \\
(0.0418)\end{array}$ & $\begin{array}{c}0.0645 \\
(0.0436)\end{array}$ \\
\hline Year & $\begin{array}{c}0.0795 * * * \\
(0.0189)\end{array}$ & $\begin{array}{c}0.0736 * * \\
(0.0333)\end{array}$ & $\begin{array}{l}0.0567 * \\
(0.0290)\end{array}$ & $\begin{array}{c}0.1011 * * * \\
(0.0382)\end{array}$ \\
\hline Constant & $\begin{array}{c}0.2364 \\
(0.4514)\end{array}$ & $\begin{array}{l}-0.7230 \\
(0.4727)\end{array}$ & $\begin{array}{l}-0.5586 \\
(0.5161)\end{array}$ & $\begin{array}{c}0.3968 \\
(0.5562)\end{array}$ \\
\hline Combined total institution years & 1,605 & 1,605 & 1,605 & 1,605 \\
\hline
\end{tabular}

Notes: Standard errors in parentheses. ${ }^{* *} \mathrm{p}<0.01,{ }^{* *} \mathrm{p}<0.05,{ }^{*} \mathrm{p}<0.1$. Matched sample created using between 1 and 20 nearest-neighbor matches with replacement. Regression parameter estimates are available upon request; errors are clustered at the institution ID level in those regressions. Years of analysis are 2010 and 2012 through 2015.

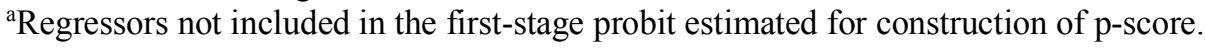




\section{ONLINE Appendix. OLS Parameter Coefficients from Oaxaca/Blinder Estimation.}

Group 1 is non-HBCU, Group 2 is HBCU.

Data Labels table:

\begin{tabular}{|ll|}
\hline \multicolumn{2}{|l|}{ Institutional characteristics } \\
\hline endowmexp_ratio & Endowment-expense ratio \\
\hline revenueperfte_1k & Revenue per fte - \$1000s \\
\hline${ }^{\text {chg2ay3_1 }}$ & In-state tuition and fees - \$1000s \\
\hline stufacr & Student to Faculty ratio \\
\hline grad_type & Graduate program $=1$ \\
\hline Student body characteristics \\
\hline par_ed_pct & Share of 1st gen. college students \\
\hline pctpel1 & Share of undergrads who receive a Pell grant \\
\hline eftot1w_total_pct & Average SAT equivalent score of students admitted \\
\hline eftot1w_total_pct & Share of female students \\
\hline efrace18_total_pct & Share of Non-Hispanic Black Students \\
\hline stemshare & Share of STEM graduates \\
\hline parttimeshare & Share of part-time students \\
\hline
\end{tabular}

Table 1 Six-year graduation rates; matched sample

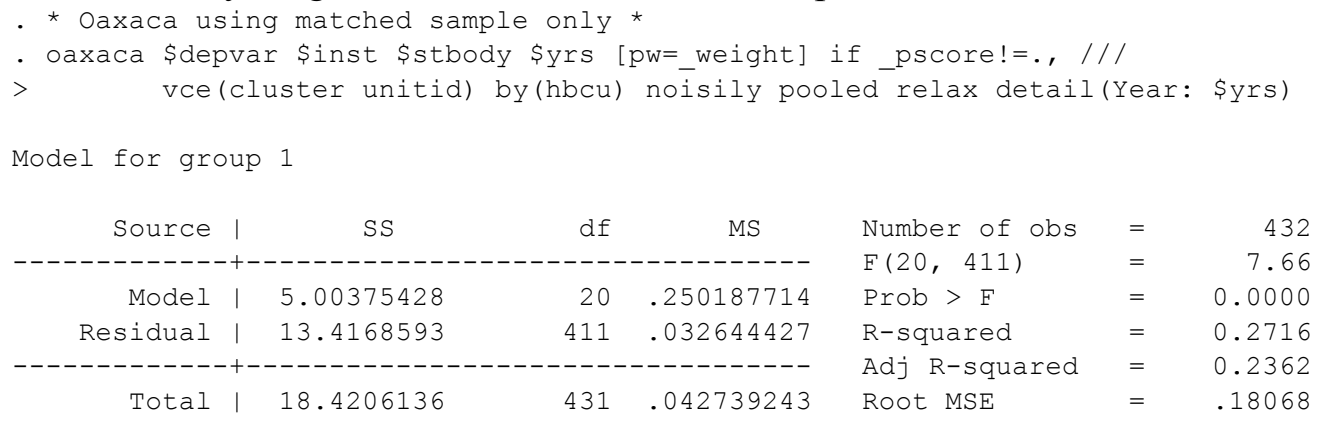

\begin{tabular}{|c|c|c|c|c|c|c|}
\hline grbkaat6year_rate | & Coef. & Std. Err. & t & $P>|t|$ & [95\% Conf. & Interval] \\
\hline endowmexp_ratio | & .0009546 & .0193435 & 0.05 & 0.961 & -.0370698 & .0389791 \\
\hline revenueperfte_1k | & .0003849 & .0002363 & 1.63 & 0.104 & -.0000796 & .0008494 \\
\hline chg2ay3_1k । & .0026253 & .0011333 & 2.32 & 0.021 & .0003976 & .004853 \\
\hline stufacr | & .0021332 & .0028324 & 0.75 & 0.452 & -.0034346 & .007701 \\
\hline grad_type | & .0376313 & .0184748 & 2.04 & 0.042 & .0013145 & .0739482 \\
\hline par_ed_pct_1stgen | & -.0036957 & .0016761 & -2.20 & 0.028 & -.0069904 & -.000401 \\
\hline pctpell । & .0002501 & .0011002 & 0.23 & 0.820 & -.0019127 & .0024128 \\
\hline sat_avg | & .000433 & .0001598 & 2.71 & 0.007 & .0001188 & .0007472 \\
\hline eftotlw_total_pct | & .0015341 & .0008186 & 1.87 & 0.062 & -.0000751 & .0031432 \\
\hline efrace18_total_pct | & -.0001936 & .0008559 & -0.23 & 0.821 & -.0018761 & .0014889 \\
\hline stemshare | & -.0003739 & .0006652 & -0.56 & 0.574 & -.0016816 & .0009338 \\
\hline parttimeshare | & -.0020508 & .0007192 & -2.85 & 0.005 & -.0034647 & -.000637 \\
\hline $\operatorname{yr} 28 \mid$ & -.028271 & .0376881 & -0.75 & 0.454 & -.1023565 & .0458144 \\
\hline yr29 । & -.0295933 & .0345392 & -0.86 & 0.392 & -.0974888 & .0383023 \\
\hline$y=30 \mid$ & -.0376772 & .0391298 & -0.96 & 0.336 & -.1145967 & .0392422 \\
\hline yr31 । & -.0365972 & .0373126 & -0.98 & 0.327 & -.1099445 & .0367502 \\
\hline yr32 । & -.0192741 & .0388838 & -0.50 & 0.620 & -.0957101 & .0571619 \\
\hline yr33 । & -.046116 & .0367388 & -1.26 & 0.210 & -.1183354 & .0261033 \\
\hline yr34 । & -.0214696 & .041107 & -0.52 & 0.602 & -.1022759 & .0593366 \\
\hline yr35 । & -.0010317 & .0359534 & -0.03 & 0.977 & -.0717072 & .0696439 \\
\hline yr36 । & 0 & (omitted) & & & & \\
\hline _cons I & -.0861227 & .203036 & -0.42 & 0.672 & -.4852413 & .3129958 \\
\hline
\end{tabular}


(model 1 has zero variance coefficients)

Model for group 2

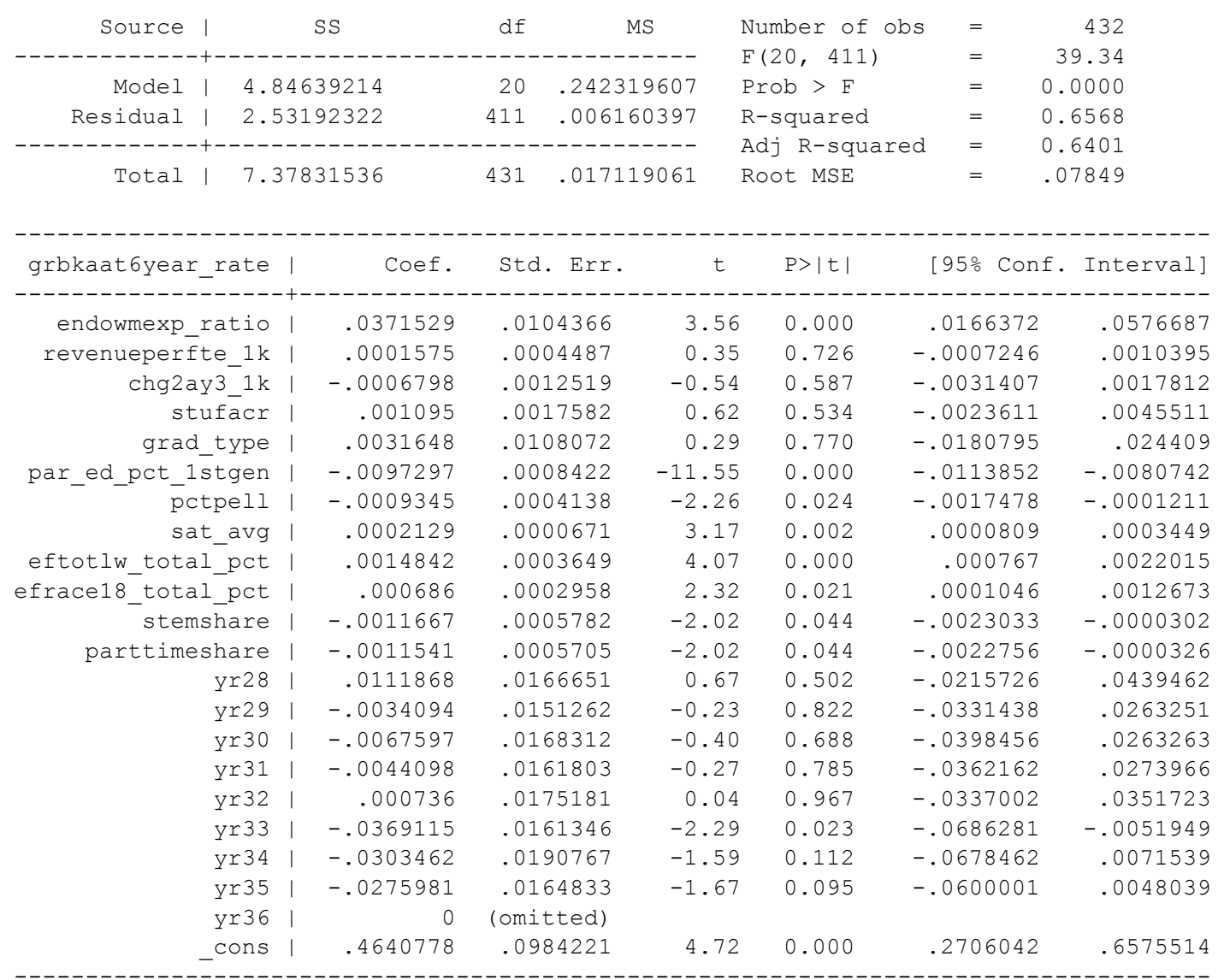

(model 2 has zero variance coefficients)

\section{Table 2 Median debt load}

. * Oaxaca using matched sample only *

- oaxaca \$depvar \$inst \$stbody \$yrs [pw=_weight] if_pscore!=., ///

$>\quad$ vee(cluster unitid) by (hbcu) noisily pooled relax detail(Year: \$yrs)

Model for group 1

\begin{tabular}{|c|c|c|c|c|c|c|}
\hline Source | & SS & $d f$ & MS & Number of obs & $=$ & 420 \\
\hline & & & -- & $F(20,399)$ & $=$ & 14.57 \\
\hline Model I & 13.3280331 & 20 & .666401656 & Prob $>\mathrm{F}$ & $=$ & 0.0000 \\
\hline Residual | & 18.2433166 & 399 & .045722598 & R-squared & $=$ & 0.4222 \\
\hline 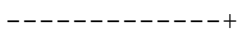 & ---1 & - & ------ & Adj R-squared & $=$ & 0.3932 \\
\hline Total I & 31.5713497 & 419 & .075349283 & Root MSE & $=$ & .21383 \\
\hline
\end{tabular}

\begin{tabular}{|c|c|c|c|c|c|c|}
\hline grad_debt_mdn_in n | & Coef. & Std. Err. & t & $P>|t|$ & [95\% Conf. & Interval] \\
\hline endowmexp ratio & .0032251 & .0234216 & 0.14 & 0.891 & -.04282 & .0492702 \\
\hline revenueperfte $1 \mathrm{k}$ | & -.0024197 & .0002643 & -9.15 & 0.000 & -.0029393 & -.0019001 \\
\hline chg2ay3_1k | & .0095939 & .0013879 & 6.91 & 0.000 & .0068654 & .0123225 \\
\hline stufacr 1 & -.0125099 & .0034248 & -3.65 & 0.000 & -.0192428 & -.0057769 \\
\hline grad_type | & .0142729 & .0221623 & 0.64 & 0.520 & -.0292966 & .0578423 \\
\hline par ed pct 1stgen & -.0047937 & .0019682 & -2.44 & 0.015 & -.008663 & -.0009244 \\
\hline petpell & -.0018567 & .0013352 & -1.39 & 0.165 & -.0044815 & .0007682 \\
\hline sat_avg | & -.0004261 & .000 & -2.21 & 0 . & -.0008044 & -.0000477 \\
\hline eftotlw_total_pct | & .0010382 & 9894 & 1.05 & 0.295 & -.0009069 & .0029834 \\
\hline efrace18_total_pct | & -.000102 & 9873 & -0.10 & 0.918 & -.002043 & .00183 \\
\hline stemshare | & & .0008004 & 1.50 & 0.134 & -.0003725 & .002774 \\
\hline parttimeshare | & -.0007999 & .000859 & -0.93 & 0.352 & -.0024887 & .00088 \\
\hline
\end{tabular}




\begin{tabular}{r|rrrrrr} 
yr28 & .0808594 & .0446772 & 1.81 & 0.071 & -.0069726 & .1686915 \\
yr29 & .1328839 & .041862 & 3.17 & 0.002 & .0505863 & .2151815 \\
yr30 & .1829357 & .0470563 & 3.89 & 0.000 & .0904264 & .275445 \\
yr31 & .1867036 & .043938 & 4.25 & 0.000 & .1003248 & .2730824 \\
yr32 & .193768 & .0467984 & 4.14 & 0.000 & .1017658 & .2857702 \\
yr33 & .212097 & .0461329 & 4.60 & 0.000 & .121403 & .302791 \\
yr34 & .1963343 & .0480762 & 4.08 & 0.000 & .1018199 & .2908487 \\
yr35 & .1880311 & .0441818 & 4.26 & 0.000 & .1011728 & .2748894 \\
yr36 & 0 & (omitted) & & & & \\
_cons & 10.48159 & .2442285 & 42.92 & 0.000 & 10.00145 & 10.96172
\end{tabular}

(model 1 has zero variance coefficients)

Model for group 2

\begin{tabular}{|c|c|c|c|c|c|c|}
\hline Source I & SS & $d f$ & MS & Number of obs & $=$ & 420 \\
\hline & & & 然 & $F(20,399)$ & $=$ & 22.70 \\
\hline Model I & 12.7746062 & 20 & .638730312 & Prob $>F$ & $=$ & 0.0000 \\
\hline Residual | & 11.2274538 & 399 & .028138982 & R-squared & $=$ & 0.5322 \\
\hline-------- & 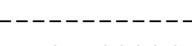 & 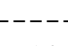 & ---------- & Adj R-squared & $=$ & 0.5088 \\
\hline Total | & 24.00206 & 419 & .057284153 & Root MSE & $=$ & .16775 \\
\hline
\end{tabular}

\begin{tabular}{|c|c|c|c|c|c|c|}
\hline grad_debt_mdn_in n | & Coef. & Std. Err. & $t$ & $P>|t|$ & [95\% Conf & Interval] \\
\hline endowmexp_ratio | & -.0687796 & .0223767 & -3.07 & 0.002 & -.1127706 & -.0247886 \\
\hline revenueperfte_1k | & -.0021761 & .0009679 & -2.25 & 0.025 & -.0040789 & -.0002732 \\
\hline chg2ay3_1k | & .0083967 & .0026888 & 3.12 & 0.002 & .0031107 & .0136826 \\
\hline stufäer | & .0067124 & .0038031 & 1.76 & 0.078 & -.0007642 & .0141891 \\
\hline grad_type | & -.0062284 & .0232795 & -0.27 & 0.789 & -.0519942 & .0395375 \\
\hline par_ed_pct_1stgen | & -.0077886 & .0018308 & -4.25 & 0.000 & -.0113878 & -.0041894 \\
\hline pctpell | & .0046171 & .0009437 & 4.89 & 0.000 & .0027619 & .0064724 \\
\hline sat_avg | & -.000154 & .0001447 & -1.06 & 0.288 & -.0004383 & .0001304 \\
\hline eftotlw_total_pct | & .0000315 & .0007808 & 0.04 & 0.968 & -.0015036 & .0015665 \\
\hline efrace18_total_pct | & .0010916 & .0006521 & 1.67 & 0.095 & -.0001904 & .0023736 \\
\hline stemshare | & -.0067319 & .0012423 & -5.42 & 0.000 & -.0091742 & -.0042896 \\
\hline parttimeshare | & -.0070756 & .0012207 & -5.80 & 0.000 & -.0094753 & -.0046759 \\
\hline $\operatorname{yr} 28 \mid$ & .0822716 & .0363227 & 2.27 & 0.024 & .0108639 & .1536794 \\
\hline yr29 | & .1253299 & .0327366 & 3.83 & 0.000 & .0609722 & .1896877 \\
\hline yr30 | & .1820228 & .0365317 & 4.98 & 0.000 & .1102042 & .2538415 \\
\hline yr31 | & .2152462 & .0353897 & 6.08 & 0.000 & .1456727 & .2848197 \\
\hline yr32 | & .2615026 & .0383688 & 6.82 & 0.000 & .1860722 & .3369329 \\
\hline yr33 | & .2620986 & .035186 & 7.45 & 0.000 & .1929255 & .3312717 \\
\hline yr34 | & .2570874 & .041128 & 6.25 & 0.000 & .1762328 & .3379421 \\
\hline yr35 | & .272165 & .035749 & 7.61 & 0.000 & .201885 & .342445 \\
\hline $\operatorname{yr} 36$ & 0 & (omitted) & & & & \\
\hline cons l & 10.15676 & .2125181 & 47.79 & 0.000 & 9.738963 & 10.57455 \\
\hline
\end{tabular}

(model 2 has zero variance coefficients)

\section{Table 3 Median earnings 10 years after matriculation}

. * Oaxaca using matched sample only *

- oaxaca \$depvar \$inst \$stbody \$yrs [pw= weight] if pscore!=., ///

$>\quad$ vee(cluster unitid) by (hbcu) noisily pooled relax detail (Year: \$yrs)

Model for group 1

\begin{tabular}{r|rrr} 
Source | & SS & df & MS \\
Model | & 6.06910077 & 16 & .379318798 \\
Residual | & 5.17607994 & 215 & .02407479 \\
--0 & \\
Total | & 11.2451807 & 231 & .048680436
\end{tabular}

$\begin{array}{llr}\text { Number of obs } & = & 232 \\ \text { F }(16,215) & = & 15.76 \\ \text { Prob }>\text { F } & = & 0.0000 \\ \text { R-squared } & = & 0.5397 \\ \text { Adj R-squared } & = & 0.5055 \\ \text { Root MSE } & = & .15516\end{array}$

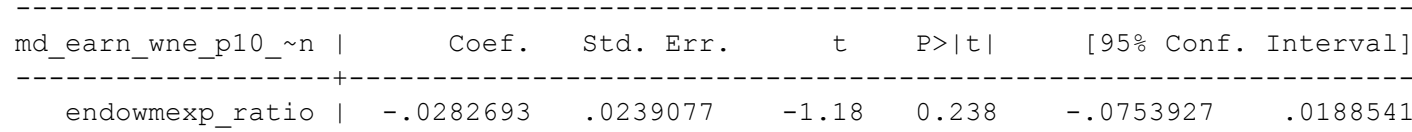

online appendix - 3 


\begin{tabular}{|c|c|c|c|c|c|c|}
\hline revenueperfte_1k & .000318 & .0002857 & 1.11 & 0.267 & -.0002451 & .0008811 \\
\hline chg2ay3_1k & .0077515 & .0013721 & 5.65 & 0.000 & .0050469 & .0104561 \\
\hline stufācr & .0005786 & .003547 & 0.16 & 0.871 & -.0064128 & .00757 \\
\hline grad_type & .0408132 & .0215691 & 1.89 & 0.060 & -.0017008 & .0833272 \\
\hline par_ed_pct_1stgen & .0014717 & .0020347 & 0.72 & 0.470 & -.0025387 & .0054822 \\
\hline $\bar{p}$ ctpell & -.0037056 & .00146 & -2.54 & 0.012 & -.0065833 & -.0008279 \\
\hline sat_avg & .0003477 & .0001869 & 1.86 & 0.064 & -.0000208 & .0007161 \\
\hline eftotlw_total_pct & -.003648 & .0009881 & -3.69 & 0.000 & -.0055957 & -.0017004 \\
\hline efrace18 total pct & .0008609 & .0010381 & 0.83 & 0.408 & -.0011853 & .002907 \\
\hline stemshare & .0020518 & .0008534 & 2.40 & 0.017 & .0003698 & .0037338 \\
\hline parttimeshare & .000073 & .0008374 & 0.09 & 0.931 & -.0015777 & .0017236 \\
\hline$y \_28$ & .0466049 & .0386348 & 1.21 & 0.229 & -.0295465 & .1227562 \\
\hline yr29 & 0 & (omitted) & & & & \\
\hline yr30 & 0 & (omitted) & & & & \\
\hline yr31 & -.0237174 & .0323462 & -0.73 & 0.464 & -.0874737 & .0400389 \\
\hline yr32 & -.0223712 & .0344847 & -0.65 & 0.517 & -.0903427 & .0456003 \\
\hline yr33 & .0164062 & .0335864 & 0.49 & 0.626 & -.0497946 & .082607 \\
\hline _cons & 10.42074 & .2372306 & 43.93 & 0.000 & 9.953141 & 10.88833 \\
\hline
\end{tabular}

(model 1 has zero variance coefficients)

Model for group 2

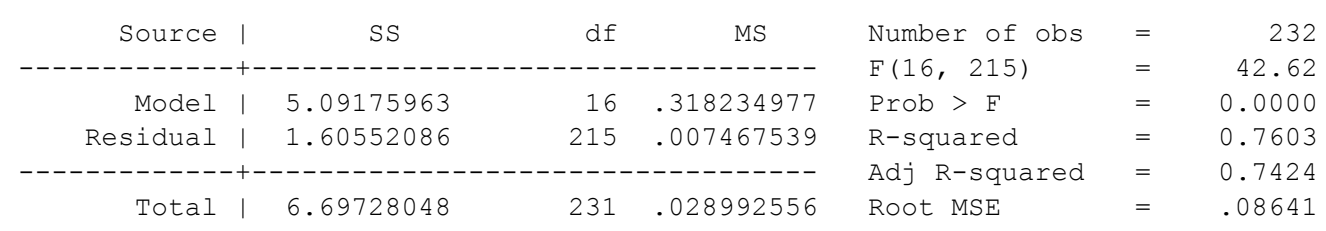

\begin{tabular}{|c|c|c|c|c|c|c|}
\hline md_earn_wne_p10_ n । & Coef. & Std. Err. & t & $P>|t|$ & [95\% Conf. & Interval] \\
\hline endowmexp ratio | & .0602757 & .0160939 & 3.75 & 0.000 & .0285538 & .0919976 \\
\hline revenueperfte_1k | & .0012311 & .000714 & 1.72 & 0.086 & -.0001762 & .0026385 \\
\hline chg2ay3_1k l & .002654 & .0019499 & 1.36 & 0.175 & -.0011894 & .0064975 \\
\hline stufacr | & -.0006446 & .0029321 & -0.22 & 0.826 & -.0064239 & .0051347 \\
\hline grad_type | & .1237563 & .0174591 & 7.09 & 0.000 & .0893434 & .1581693 \\
\hline par_ed_pct_1stgen | & -.0011658 & .0013833 & -0.84 & 0.400 & -.0038923 & .0015607 \\
\hline pctpell | & -.0044804 & .0008205 & -5.46 & 0.000 & -.0060976 & -.0028632 \\
\hline sat_avg | & .0005774 & .0001245 & 4.64 & 0.000 & .000332 & .0008227 \\
\hline eftotlw_total_pct | & .0001551 & .0005705 & 0.27 & 0.786 & -.0009694 & .0012797 \\
\hline efrace18_total_pct | & .0003435 & .0005292 & 0.65 & 0.517 & -.0006996 & .0013867 \\
\hline stemshare | & -.0021097 & .0009088 & -2.32 & 0.021 & -.0039009 & -.0003184 \\
\hline parttimeshare | & -.0013733 & .0009577 & -1.43 & 0.153 & -.003261 & .0005145 \\
\hline yr28 | & 0 & (omitted) & & & & \\
\hline yr29 & 0 & (omitted) & & & & \\
\hline yr30 । & -.0712018 & .0215221 & -3.31 & 0.001 & -.1136231 & -.0287806 \\
\hline yr31 । & -.0847588 & .021277 & -3.98 & 0.000 & -.126697 & -.0428207 \\
\hline yr32। & -.1281729 & .0221921 & -5.78 & 0.000 & -.1719148 & -.0844309 \\
\hline yr33 । & -.0916201 & .0209192 & -4.38 & 0.000 & -.1328532 & -.050387 \\
\hline cons | & 10.18432 & .1692311 & 60.18 & 0.000 & 9.850751 & 10.51788 \\
\hline
\end{tabular}

(model 2 has zero variance coefficients) 